Strand, S. (2014). Ethnicity, gender, social class and achievement gaps at age 16: Intersectionality and 'Getting it' for the white working class. Research Papers in Education, 29,

(2), 131-171. http://dx.doi.org/10.1080/02671522.2013.767370

\author{
Professor Steve Strand \\ University of Oxford, Department of Education \\ England, UK \\ Tel: $+44(0) 1865611071$ \\ e-mail: steve.strand@education.ox.ac.uk
}

$\underline{\text { Keywords: }}$ ethnicity, gender, social class, equity, achievement, intersectionality

Word count 10,908 (excluding abstract, references, footnotes, tables and appendices)

Acknowledgment: This research was funded by the Government Department for Education (Project Reference EOR/SBU/2006/031).

Note on contributors: Steve Strand is Professor of Education at the University of Oxford. His research interests are in school effectiveness and in equity issues in student achievement (particularly ethnicity, social class and gender) and he has published widely in these areas. 


\section{Ethnicity, gender, social class and achievement gaps at age 16: Intersectionality and 'Getting it' for the white working class.}

\section{Abstract}

Perhaps the most prevailing inequalities in educational achievement in England are those associated with socio-economic status (SES), ethnicity and gender. However little research has sought to compare the relative size of these gaps or to explore interactions between these factors. This paper analyses the educational achievement at age 11, 14 and 16 of over 15,000 students from the nationally representative Longitudinal Study of Young People in England (LSYPE). At age 16 the achievement gap associated with social class was twice as large as the biggest ethnic gap and six times as large as the gender gap. However the results indicate that ethnicity, gender and SES do not combine in a simple additive fashion, rather there are substantial interactions particularly between ethnicity and SES and between ethnicity and gender. At age 16 among low SES students all ethnic minority groups achieve significantly better than White British students (except Black Caribbean boys who do not differ from White British boys), but at high SES only Indian students outperform White British students. A similar pattern of results was apparent in terms of progress age 11-16, with White British low SES students and Black Caribbean boys (particularly the more able) making the least progress. Parents' educational aspirations for their child and students' own educational aspirations, academic self concept, frequency of completing homework, truancy and exclusion could account for the minority ethnic advantage at low SES, but conditioning on such factors simultaneously indicates substantial ethnic underachievement at average and high SES. Accounts of educational achievement framed exclusively in terms of social class, ethnicity or gender are insufficient and the results challenge educational researchers to develop more nuanced accounts of educational success or failure. 


\section{INTRODUCTION}

This paper is concerned with equity gaps in educational achievement at age 16, the age at which students in England can currently choose to leave compulsory education. While achievement gaps at 16 are important in their own right, they are also important because attainment age 16 is so strongly related to long term outcomes such as continuing in full-time education after age 16, entry to higher education and university, employment chances, wages and anti-social behaviour (Boudon, 1974; Mclntosh \& Vignoles, 2000, Kingdon \& Cassen, 2010). In this paper the focus is on equity in relation to three dimensions: ethnic group, social class and gender.

Ethnic minority students constitute almost one-quarter (24.5\%) of the population in primary and secondary schools in England (DFE, 2011), a substantial increase from $14.2 \%$ in 2003 (DFES, 2003)i. The largest minority groups are Indian (2.6\%), Pakistani (4.2\%), Bangladeshi (1.7\%), Black African (3.2\%), Black Caribbean (1.4\%) and mixed heritage (4.6\%) students. For quite some time there has been concern over the educational achievement of students from some ethnic minority groups. Early work in the UK was summarised in the committee of inquiry into the education of children from minority ethnic groups (the Swann report) which concluded that Black Caribbean children as a group "are underachieving in our education system" (DES, 1985, p3). While there is evidence of substantial change in the attainment of some ethnic groups over the last 20 years (see Strand et. al., 2010), a recent topic review from the Department for Education highlights the continued achievement gaps in relation to ethnicity (DfES, 2006). The most recent 2011 national data on attainment at age 16, using the threshold of achieving five or more GCSE passes at $A^{*}-C$ grades including English and mathematics, indicates the performance of Black Caribbean (48.6\%), Pakistani (52.6\%) and Black African (57.9\%) groups is below that of their White British peers (58.2\%), while the achievement of Bangladeshi (59.7\%) and Indian (74.4\%) students is higher (DFE, 2011).

The strong relationship between socio-economic status (SES) and educational attainment is one of the most widely documented features of educational research, revealed in studies not only in England (e.g., Douglas, 1964; Bynner \& Joshi, 2002) but across many industrialised countries (e.g., Coleman, 1966; White, 1982; Sirin, 2005; OECD 2011). Social class may have a direct influence on children's development, for example through limited material resources and an increased risk of a range of health and developmental problems (Spencer, 1996; McLoyd, 1998) and an indirect influence through parental education, expectations and aspirations (e.g., Phillips, Brooks-Gunn, Duncan, Klebanov \& Crane, 1998). Again, a recent topic review from the Department for Education highlights the continued achievement gaps in 
relation to socio-economic disadvantage in contemporary data in England (DCSF, 2009). The most recent 2011 results show only $34.6 \%$ of students entitled to a Free School Meal (FSM), a commonly used indicator of family poverty, achieved 5 or more $A^{*}-C$ grades including English and mathematics compared to $62.0 \%$ among those not entitled to FSM (DFE, 2011).

With regard to gender, despite earlier concerns with girls lower achievement and lack of access or interest in areas of the curriculum such as science and mathematics (e.g. Beller and Gafni, 1996; Archer and McDonald, 1991), since the late 1980's girls in England have out-performed boys at age 16 , scoring on average $10 \%$ points higher than boys in terms of the proportion achieving 5 or more $A^{*}-C$ grades at GCSE, although the gap is particularly large in relation to English and language subjects. Again a recent topic review from the Department for Education highlights the achievement gaps in relation to gender (DCSF, 2007) in contemporary data in England. The most recent 2011 results show $54.6 \%$ of boys achieved $5+A^{*}-C$ including English and mathematics compared to $61.9 \%$ of girls (DFE, 2011).

Clearly not all 'gaps' are equally large, however little research has sought to compare the relative size of ethnic, social class and gender gaps. For example analysis of the Youth Cohort Study (YCS) in England suggests that social class differences in attainment are larger than ethnic differences, which in turn are larger than gender differences (Demack, Drew and Grimsley, 2000; Gillborn \& Mirza, 2000). Most recently Strand (2011) indicates the social class gap in achievement at age 14 in England was six times larger than the gender gap and three times larger than the ethnic gap (p203). Importantly though, it may be misleading to consider these gaps in isolation. There is substantial overlap between ethnicity and low SES in England, as there is in other countries of Western Europe and in the US (OECD, 2011; US Census Bureau, 2006). For example in secondary schools in England 11\% of White British students are eligible for a FSM compared to $9 \%$ of Indian, $23 \%$ of Black Caribbean, $30 \%$ of Pakistani, 35\% of Black African and $43 \%$ of Bangladeshi students (DCSF, 2009). Any examination of ethnic gaps in educational achievement should take account of this substantial overlap and indeed increasingly there is a move to explain ethnic group variations in attainment that remain after the effects of SES are statistically removed (e.g. Philips et al, 1998; Fryer \& Levitt, 2004, 2006).

Research in England on ethnic gaps at age 16 after control for SES indicate mixed results. The main source of representative data in England to monitor the educational achievement of 16 years olds by ethnicity, gender and social class has been the Youth Cohort Study (YCS). This survey has been completed approximately every two years since 1985 randomly sampling between $13,000-15,000$ students on each occasion. Demack et. al. (2000) using the 
YCS 1988-1995 report that ethnic gaps still persist even when gender and social class were taken into account. Similarly Connolly (2006) analysing the 1997-2001 sweeps, and Rothon (2007) analysing the 1991-2001 sweeps, both indicate that significant ethnic differences remain after control for SES. More recently using the England National Pupil Database (NPD) Wilson, Burgess \& Briggs (2011) report that Black Caribbean students still had lower attainment at age 16 than White British students after control for age, poverty, gender, special educational needs and neighbourhood deprivation (although the difference was less than 0.10 SD) and similar results are reported by Dustmann, Machin and Schonberg (2010) after control for EAL and FSM. In contrast Kingdon and Cassen (2010) using NPD data from 2003 indicate that after control for FSM, gender, age, SEN, and pupil mobility, Black Caribbean students are no more likely than White British students to be low achievers.

These studies have broadly been interested in SES and gender only as control variables in evaluating ethnic gaps, and this is typical of the vast majority of studies. However there is a subtler possibility, namely that there is something about the particular combination of ethnicity, SES and gender that is uniquely related to attainment. There is a tradition of interest in intersectionality in qualitative research, often concerned with the concept of multiple identities (e.g. Archer \& Francis, 2007). However it is perhaps surprising how rarely quantitative educational research in the area explicitly considers potential interactions between ethnicity, gender and class. Most of the studies reported above have not explicitly tested for interaction effects (e.g. Wilson et al., 2011, Dustmann et al., 2010). Where interactions have been tested researchers have often suggests simple additive models are sufficient to model the relationship of attainment with ethnicity, gender and social class. For example Connolly (2006) reports no evidence of any systematic variation in the size of gender differences in attainment across ethnic or social class groups, or in the size of social class differences across ethnic groups, and argues that social class, ethnicity and gender can be understood in terms of a simple additive model. Rothon (2007) reaches a similar conclusion that "social class operates in a similar way for all ethnic groups without a specifically 'ethnic effect' that mitigates its impact in certain groups" (p306).

However, significant interactions between ethnicity, SES and gender have been reported. In a longitudinal analysis of the educational attainment and progress of a national cohort of 530,000 students aged 11 in England, Strand (2010) found significant interactions between ethnicity and entitlement to FSM with White British students entitled to FSM showing the lowest levels of achievement and progress, comparable to their Black Caribbean peers but well below all other ethnic groups. The study also reports strong interactions between ethnicity and gender with Black African and Black Caribbean girls making significantly more progress 
than boys (p295). At age 16, Kingdon and Cassen (2010) identify that economic disadvantage has a stronger effect on White British students than those of ethnic minorities, and also that the gender gap was particularly large for many ethnic groups relative to the gap for White British students. Dekkers, Bosker \& Driessen (2000) completed a longitudinal analysis of a representative sample of 20,000 Dutch students age 12-18 and report significant two-way interactions between all of ethnicity, gender and SES. The attainment of girls from ethnic minorities was better than expected, while that of majority boys from low SES backgrounds was worse when compared to similar boys from ethnic minorities. Similar results are reported by Storen \& Helland (2010) looking at upper secondary school completion rates in Norway.

Returning to the most recent national data at age 16 reported earlier (DFE, 2011), Table 1 and Figure 1 present the proportion of pupils achieving five or more GCSE at $A^{*}-C$ including English and mathematics separately for each ethnic group and FSM combination. The data suggests a strong interactive effect. While White British pupils achieve as well or better than most ethnic groups among those not entitled to FSM (62.0\% compared to $56.8 \%$ of Pakistani and $52.0 \%$ of Black Caribbean students), among those entitled to FSM they are the lowest achieving ethnic group (28.8\% compared to $37.8 \%$ of Black Caribbean and $42.9 \%$ of Pakistani students). Looked at another way, the FSM gap is 33.2 percentage points among White British students, more than double the FSM gap within Pakistani (13.9\%) and Black Caribbean (14.2\%) groups. In short, to understand ethnic group differentials in attainment it may not be sufficient to control for SES so much as to explore why the 'effect' of SES varies across ethnic groups (or equally the 'effect' of ethnicity varies across levels of SES). In interpreting such interactions attention needs to be directed to the role of other mediating factors, and the greater resilience to low SES among many minority ethnic groups may be ascribed to the importance of aspirational cultures particularly among Asian and Black African groups (e.g. Cheng \& Starks, 2002; Kao \& Tienda, 2003; Strand \& Winston, 2008, Strand, 2011). By the same token studies focussing on White Working class students have highlighted low student and parent educational aspirations, perpetuated by factors such as low literacy levels, feelings of marginalisation, a lack of community and school engagement and lack of targeted support to break the poverty cycle (Demie \& Lewis, 2011, p254) as well as inter-generational poverty and its effects on aspirations in deprived communities (DCSF, 2008). However aspirational factors alone are unlikely to reveal the whole story, since an account is needed not only of the greater resilience of ethnic minority students from low SES backgrounds, but also the underachievement of many of these groups among those from high SES backgrounds. This study seeks to establish not only the size and significance of ethnic by SES interactions, but also the extent to which these can be accounted for by a wide range 
of explanatory factors such as parental and students attitudes and behaviours and other family or school/neighbourhood factors (see further detail below).

$\leftarrow-----$ Insert Table 1 and Figure 1 about here ------->

Many current datasets in England are limited in relation to the above task. Very large samples are required to fill the cells in all ethnic, SES and gender combinations and in the YCS, despite relatively large overall achieved samples, the numbers are often insufficient to explore possible interactions between social class, ethnicity and gender. Additionally, the YCS only starts collecting data from age 16 and does not allow an exploration of how ethnic, gender or social class gaps develop over the course of secondary school (age 11-16). While England now has population data available from the National Pupil Database (NPD) that allow for the modelling of progress as well as attainment in relation to ethnicity and gender, there is very limited data on SES, only the crude binary indicator of entitlement to a FSM, and no detailed data on attitudes and behaviours to investigate wider student, family or school/neighbourhood factors that may impact on these gaps. Further research is needed with a longitudinal dataset that combine the benefits of large representative samples with detailed explanatory variables. The Longitudinal Study of Young People in England (LSYPE) is one such dataset which will be analysed here.

\section{Plan of the paper}

The plan of the paper is as follows. First, a 'main effects' analysis is completed to determine the unique associations of SES, ethnicity and gender with achievement at age 16. Second, specific tests for the presence of interactions between SES, ethnicity, and gender are completed to identify whether there are particular groups of students (defined by the intersections of SES, ethnicity and gender) who are under-performing. Third, we move beyond description to explore a range of explanatory variables at the parent, student, and school level to determine the extent to which they can account for the observed achievement gaps. Fourth, students' progress between age 11 and age 16 is analysed to determine whether observed gaps at age 16 were already present at age 11, and whether gaps widen or narrow over the course of secondary education. The same tests for interaction and contextual effects are examined to see whether these can account for gaps in progress. The final section reviews and considers the implications of the results. 


\section{METHODOLOGY}

\section{Sample}

Wave 1 of the Longitudinal Study of Young People in England (LSYPE) occurred in summer 2004, and the target population was young people in Year 9 (age 14) in all schools in England. LSYPE used a two stage sampling procedure. At the first stage a sample of schools was drawn with probability proportionate to size from a frame stratified by school deprivation status, region and school admission policy (comprehensive, selective and secondary modern) and at the second stage a sample of students in Year 9 was drawn from the schools. The survey was specifically designed to support analyses in relation to ethnic group through sample boosts for the six largest minority ethnic groups: Black African; Black Caribbean; Bangladeshi; Indian; Pakistani and students of Mixed heritage. These boosts provided representative samples of the relevant sub-populations as a whole, rather than drawing disproportionately from areas or schools with high numbers of minority ethnic students. The achieved sample consisted of 15,570 students drawn from 658 schools. After excluding students who had no age 16 scores, those whose main parent was not interviewed or those missing three or more of the SES variables (see below) the eligible sample was 15,208 students drawn from 629 schools with an average number of students per school of 22.7 (range 1 to 45 , SD 5.3). In the analyses to follow the data have been weighted to compensate for differential selection chances in the sample design and to remove non-response biases. Additionally standard errors are adjusted for clustering at the primary sampling unit (school) level. Analyses were completed using the SPSS Complex Samples module V18.0.

\section{Measures}

LSYPE data collection was based on face to face interviews with the young person and with both parents/carers (where present). The data was linked to the School Census and to the students' national test results at age 11 in 2001, age 14 in 2004 and public examination results at age 16 in 2006. All student background variables were drawn from Wave 1 when the students were aged 14 (2004). The variables used in the analysis are described below.

\section{Ethnic group}

Information on students' ethnic group was collected through self-identification from 16 ethnic categories (plus don't know/refused). The rationale for the LSYPE sampling strategy was to focus on the attainment of White British students and the six main minority ethnic groups in England, hence ethnic group was collapsed into seven categories plus a generic 'any other group'. The seven categories were White British, Mixed heritage, Indian, Pakistani, 
Bangladeshi, Black Caribbean and Black African which together accounted for $96 \%$ of all students interviewed.

\section{Gender}

Girls were coded 1 and boys were coded 0 .

\section{$\underline{\text { Socio-Economic Status (SES) }}$}

The socio-economic classification of the home (SEC) is a central indicator of SES, but SES is often considered to include wider dimensions such as parental education, family income, housing status, entitlement to a Free School Meal (FSM) or neighbourhood deprivation (e.g. White, 1982; Sirin, 2005). Preliminary analysis of the LSYPE data indicated significant interactions between ethnic group and a wide range of such SES variables (see Strand, 2008, p21-24). This established the generality of the finding across a wide range of measures of SES but produced very complex models with multiple interaction terms making interpretation problematic. Consequently a single composite measure of SES was derived from the following five socio-economic variables:

Socio-economic classification of the home (SEC): The SEC of the head of the household was coded by matching their occupation/size of organisation using the Office of National Statistics (ONS) eight SEC analytic classes, ranging from 'higher managerial and professional occupations' through to' never worked or unemployed for the last six months or more'.

Parents' highest educational qualifications: The highest educational qualification of the student's main or second parent (whichever was the higher) was measured over six categories ranging from 'degree or above' through to 'no educational qualifications'.

Entitlement to a Free School Meal (FSM): A binary indicator which is widely used as a measure of family poverty since only students from families in receipt of state benefits such as income support, jobseekers allowance or child tax credits are eligible for FSM.

Home ownership: A binary indicator of whether the family owned or rented their home. Home ownership provides a measure of SES in England where many families aspire to own their own home and there is relatively little Local Authority or social housing.

Neighbourhood deprivation: The Income Deprivation affecting Children Index (IDACI) is produced by central government and measures the proportion of children under the age of 16 in an area living in low income households. The indicator is available for very localised areas called super output areas (SOA) of which there are 32,000 in England, each containing approximately 1,500 people and 200 children $(S D=70)$. 
Prior to analysis 38 cases with less than three of the five SES variables were omitted. A nonlinear Principal Component Analysis (PCA) was then completedii using the CATPCA programme in SPSS version 18 (see Meulman et al, 2004). The scaling level for all variables was ordinal, except for IDACI score which was modelled through a nonmonotonic spline. Passive treatment of missing data was used to ensure that a case with a missing value on one variable did not contribute to the solution for that variable but did contribute to the solution for all other variables, with a separate additional category fitted for missing values on each variable. The first principal component explained $54.5 \%$ of the variance with a Cronbach's alpha of 0.88 . The SES composite score reflected the component loadings on this principal component with the more differentiated measures (SEC, parent's educational qualifications and IDACI) double weighted compared to the simple binary variables (FSM and home ownership). The resulting variable was subject to a normal score transformation (so that the mean was zero and SD was 1) prior to further analysis.

\section{Other explanatory variables}

The study collected a wide range of quantitative data about the attitudes, expectations and behaviours of the students and their families, drawn from separate face-to-face interviews each of 45 minutes duration conducted with the student and with their parent/s in their own homes. Other data were drawn from the January student level School Census. Further explanatory variables, beyond ethnic group, gender and SES, were organised into blocks based on a theoretical model of the nature of various influences on educational attainment (Powdthavee, Levacic \& Vignoles, 2006). The three main blocks were composed of:

- Parental attitudes and behaviour. A set of variables entered before any individual student variables on the presumption that family influences logically precede or at least create the context for individual student attitudes and behaviour. These variables included: family composition (single or dual carer households), parental involvement in school, parents' educational aspirations for the student, provision of material resources such as a home computer and private tuition, the quality of family relationships (frequency of parent reported quarrelling with the child);

- Student risk and resilience factors: these included risk factors associated with an increased likelihood of low attainment, specifically: Special Educational Needs, truancy, exclusion, long term absence, problems leading to the involvement of the police and/or education welfare and social services. They also included protective factors associated with higher attainment, specifically: educational aspirations (remaining in FTE after age 16), planning for the future, attitude to school, academic 
self concept, number of evenings per week the student reported completing homework.

- School context: school type (Church, Foundation or Community school), school admissions status (comprehensive, secondary modern or grammar school) and school deprivation (percentage of students entitled to FSM).

The division of variables between these blocks is not a rigid demarcation but is a useful way of structuring the wide range of data available through LSYPE. There is relatively little evidence of the mechanisms through which achievement gaps are mediated. By entering these measures after SES, ethnicity and gender it is possible to explore whether these factors influence or mediate equity effects, in which case we might expect to both improve the prediction of educational achievement and to reduce the relative impact of SES, ethnicity or gender. Twenty-seven specific variables were created and are fully described in Strand (2011) where Appendix 1 gives a full description of the definition and coding of each variable.

\section{Educational attainment}

Age 11 average test score: The outcome variable for each student is the average test marks achieved across all the three subjects tested in statutory national tests at age 11: English (reading, writing and spelling); mathematics (mental maths and two written papers, one allowing and one not allowing the use of calculators) and Science (two written papers). To aid interpretation average age 11 test marks (range 0-280) was subject to a normal score transformation so that the mean is zero and SD is 1 .

Age 14 average test score: At the end of Year 9 students again complete national tests in English, mathematics and science. The actual test marks obtained by each student, and the test tier to which they were entered, were used to generate 'fine grained' test levels on a decimal scale. These fine grained levels were combined to create an average points score which was subject to a normal score transformation so that the mean is zero and SD is 1.

Age 16 points score: two different measures of examination score at age 16 were created: (a) total points score, and (b) core subject points score which was the average of GCSE English, mathematics and science grades. These measures give slightly different perspectives on attainment at age 16 . Total points score gives credit to any and all qualifications and is the most inclusive measure of attainment at age 16 and is a measure reported in secondary school performance tables. Core subjects points score is not generally reported, but by giving an indication of performance in the three core subjects may be more 
comparable to assessment at age 11 and age 14 which focus just on the three subjects of English, maths and science and reflects the fact that GCSE English and mathematics are seen as key indicators of basic skills acquisition iii. Despite the different nature of the two measures, results indicated very similar patterns whichever outcomes was employed. Therefore, the most inclusive measure, total points score (TPS), was favoured in the main analysis. To aid interpretation points scores were subject to a normal score transformation to give a mean of zero and SD is 1.

\section{Treatment of missing data}

Because of the large number of variables to be employed in the analysis listwise deletion would rapidly reduced the sample size to around 9,000 cases. To prevent such data loss missing values were explicitly included as dummy categories within each variable. See Strand (2011) for a discussion of the advantages of this approach.

\section{RESULTS}

\section{Descriptive Statistics}

Table 2 presents the mean age 16 points score for each ethnic, gender and SES group. The SES gap (contrast between top and bottom SES quintiles) was by far the largest at 1.31 SD. There were also significant ethnic gaps in attainment. Relative to the majority group of White British students, Indian students scored significantly higher (.34 SD) and Black Caribbean scored significantly lower (-.29 SD) a range of $.63 \mathrm{SD}$. The gender gap was relatively small at .23 SD in favor of girls. What is clear is that not all gaps are of the same size, SES is by far the largest gap, about twice as large as the biggest ethnic gap ${ }^{\text {iv }}$ and six times larger than the gender gap.

$$
<--- \text { Insert Table } 2 \text { about here ---- > }
$$

However these gaps are related, in particular there is a strong confound between ethnicity and SES. Table 3 and Figure 2 present a breakdown of SES by ethnic group. The mean SES score of all ethnic minority groups is significantly lower than for White British students. The mean SES is particularly low for Bangladeshi (-1.67), Pakistani (-.87), Black African (-.87) and Black Caribbean (-.56) students. Hence the 'raw' results presented in Table 1 may overestimate the size of the ethnic gaps if at least a part of these gaps may be more directly attributable to SES. To analyse the unique impact of ethnicity, SES and gender we turn to multiple regression analysis.

$$
\text { <--- Insert Table } 3 \text { and Figure } 2 \text { about here ---- > }
$$




\section{Contextual analysis of attainment at age 16}

\section{Model 1: Ethnicity, gender and SES (main effects)}

Table 4 presents the results of five hierarchical multiple regression analyses for age 16 average test score. Model 1 shows the results when ethnic group, gender and SES are entered jointly in a multiple regression. The ethnic gaps change markedly after the associations with SES are taken into account. Indian and Any Other ethnic group scored significantly higher than White British students in terms of 'raw scores' (see Table 2), and this increased even further after accounting for SES. Bangladeshi, Black African and Mixed heritage groups, who did not differ significantly from White British students in raw scores, now score significantly higher than White British students. Pakistani and Black Caribbean students were the only ethnic groups with raw scores significantly below White British students, but after adjusting for SES the Pakistani mean is significantly higher than White British and the White British-Black Caribbean gap is no longer statistically significant. The analysis appears to indicate that all ethnic groups achieve at least as well, and in most cases significantly better, than White British students after SES is taken into account. Figure 3 presents the predicted scores by ethnic group and SES based on the main effects model.

$$
\text { <--- Insert Table } 4 \text { and Figure } 3 \text { about here ---- > }
$$

\section{Model 2: Ethnicity, gender and SES (with interaction terms)}

Model 2 explicitly tests the statistical significance of interactions between ethnicity, gender and SES. The three way interaction between ethnicity, gender and SES was not significant, and neither was the SES by gender interaction. However there were significant and substantial interactions between ethnic group and SES, and less marked but still substantial interactions between ethnic group and gender. The SES gradient was particularly steep for White British students and significantly less so for all other ethnic groups (except Mixed heritage). Also White British girls did better than boys, but this gender gap in favour of girls was significantly larger among Bangladeshi and Black Caribbean students. Table 5 and Figure 4 aid interpretation by presenting the mean scores for all combinations of ethnic group, gender and SES.

Insert Table 5 and Figure 4 about here

The ethnic coefficients shown in Table 4 (model 2) and the significance tests are specifically against the reference group, which is White British, boys at mean SES. Given the significant interactions terms, Table 5 present a full set of significance tests for the contrasts between 
each minority ethnic group and White British students at each of three levels of SES (-1SD below the mean, the mean and 1SD above the mean) and separately for boys and girls. Tests at different levels of SES were conducted by transforming the 0 point of the SES scale and by reversing the gender of the reference group (See Jaccard \& Turrisi, 2003). It will be remembered that the results of the main effects analysis suggested that after adjusting for SES all minority ethnic groups scored significantly higher than White British, except for Black Caribbean who did not differ significantly from White British (See Figure 3). However this pattern was consistent only with the results for low SES boys, where White British and Black Caribbean boys were jointly the lowest scoring groups (around -.50 SD). For low SES girls, Black Caribbean joined the other minority groups in scoring significantly higher than White British, making White British girls the lowest scoring group (-.28 SD). At the mean SES, all ethnic groups achieved as well or better than their White British peers, except Black Caribbean boys (-.13 SD). At high SES few ethnic contrasts were significant, with only Indian (and any other ethnic group) scoring significantly higher than White British, and only Black Caribbean boys scoring significantly lower (-.27 SD) than their White British peers.

Accounting for the interaction terms significantly improved the predictive power of the model (increase $r$ squared from $23.7 \%$ to $24.0 \%, p<.001$ ). More importantly it is apparent that, in this data at least, the effects of ignoring the significant interactions between ethnicity, SES and gender lead to substantial misrepresentation of the results. This can be seen by comparing Figure 2 with Figure 3. White British students were the lowest achieving ethnic group among those from low SES backgrounds, but among the highest achieving group for those from high SES backgrounds. The lowest achieving groups in absolute terms were both low SES Black Caribbean and White British boys along with White British low SES girls. Most minority ethnic groups were better able to weather the disadvantage of low SES and their attainment did not appear so adversely effected. However the results also indicated that Black Caribbean boys from middle and high SES backgrounds (but not Black Caribbean girls) achieved significantly lower scores than their similarly advantaged White British peers, raising particular questions about why they are the only group to underachieve in this way. These results were obscured in the main effects analysis.

\section{Model 3: Parental factors}

Model 3 added seven further variables related to parents attitudes and behaviours, all of which were significantly associated with attainment. Parental expectations that the student would continue in FTE post 16 was associated with higher attainment (.52 SD), as was providing a home computer for the child to use (.37 SD), a low level of parent reported quarrelling with the student (-.29 SD and -.14 SD for quarrelling most days or more than once 
a week compared to < once a week), parental monitoring of the young person's whereabouts (.26 SD), parental involvement in three or more school activities compare to none (.14 SD), residing in a dual parent household (-.11 SD for single parent household) and providing private tuition in school subjects (.04 SD). Overall adding these variables provided a modest boost to the explanatory power of the model raising the percentage of the variance explained from $24.0 \%$ to $32.4 \%$. These factors reduced the overall impact of SES for all ethnic groups. They also appeared to account for the higher scores (at mean SES) of the Pakistani and Bangladeshi groups and a substantial portion of the higher scores of Indian and mixed heritage students. On average parents in these ethnic groups were more likely than White British parents to have paid for private tuition, more involved with their child's school, had higher educational aspirations for their children, were more likely to know where their children were when they were out, less likely to quarrel with their child and less likely to be single parent households. However they did not explain the lower achievement of the Black Caribbean students, despite their parents also sharing several of the above advantages, and the Black Caribbean coefficient (at the mean SES for boys) increased from -.13 to -.23 SD.

\section{Model 4: Student risk and resilience factors}

This stage added a further eleven explanatory variables related to student level factors and these substantially improved the amount of variance explained from $32.4 \%$ to $49.7 \%$. The most substantial influences were academic self concept with a .66 SD difference between the very high and very low groups; amount of homework with a .31 SD difference between those completing homework every evening vs. those never completing homework; planning for the future with .20 SD difference between the top and bottom bands and student educational aspirations with a .26 SD boost for those students planning to continue in FTE post 16 (in addition to the effect of parents' educational aspirations). There were negative associations between attainment and SEN (-.58 SD), extended absence from school (-.26 SD), having being temporarily or permanently excluded from school anytime during Y7-Y9 (-.26 SD), involvement with police and/or social services (-.20 SD for involvement with one and -.35 SD for involvement with both) and truanting from school (-.16 SD).

These variables explained even more of the SES effect, reducing the SES coefficient (for White British boys) from 1.0 SD in model 2 to .42 SD, a reduction of nearly $60 \%$. These factors explained the higher scores of Indian and mixed heritage students relative to White British students. However the effect of including these variables turned the coefficients (at mean SES for boys) for Bangladeshi, Pakistani and Any Other group significantly negative relative to White British. Again this is because most minority ethnic groups were more advantaged on these measures than White British students. On average minority students 
were more likely to aspire to continue in education post 16 , to have a positive academic self concept, to plan for the future and to have a positive attitude to school, and less likely to have been excluded (except Black Caribbean students) or to have had extended absence (except for Pakistani students). All these are advantaging factors across the sample as a whole, as shown by their coefficients, but they were not associated with proportionately greater attainment within the minority ethnic groups. It was also notable that these factors did not alter the coefficient for Black Caribbean boys which still shows a large negative effect (-.23 SD).

\section{Model 5: School factors}

The last model added three school level variables which accounted for a very modest increase in the percentage of variance explained from $49.7 \%$ to $51.3 \%$. This model included no controls for prior attainment, so some of these school variables may reflect differences in the attainment of the intake to different types of schools (see later for 'value added' analyses of student progress). Students attending grammar schools scored on average .58 SD higher, and students in secondary modern schools -.10 SD lower, than students attending comprehensive schools; students in the most deprived schools (35\% or more entitled to FSM) on average scored -.18 SD lower than those in the least deprived schools ( $<5 \%$ entitled to FSM); and students in Church schools scored .08 SD higher than students in community schools. These variables explained a small further part of the overall SES effect relative to model 4 (reduced from .42 SD to .36 SD) but made only a small difference to the ethnic coefficients. Minority ethnic students were more likely to attend deprived schools, and less likely (except Indian students) to attend grammar schools, so the gaps for Pakistani, Bangladeshi, Black Caribbean and Black African groups relative to White British closed very slightly but were still highly significant. Table 6 presents the estimated age 16 points scores by ethnic group, gender and SES after adjustment for all the contextual variables included in Model 5.

$<$ Insert Table 6 about here

\section{Summary of contextual modelling}

The contextual variables more than double the amount of variation in age 16 score that can be explained, from $24.0 \%$ in model 2 to $51.3 \%$ in model 5 . This indicates that even where the SES variable is multi-faceted and differentiated, as it is here, predictions for individual students based on their SES still have a large margin of error. The contextual variables are able to explain a substantial part of the SES effect so that, looking at White British boys, the SES gap has decreased from 1.0 SD to .36 SD, a reduction of $64 \%$ or almost two-thirds ${ }^{v}$. So much of the SES effect is mediated by the parental support variables and the student risk and 
resilience variables. These contextual variables are also able to explain much of the attainment differential between White British and ethnic minority groups at low SES (see Table 6). However it is notable that these same contextual factors have a disproportionate effect on the adjusted scores for average and high SES ethnic minority students. Table 6 shows that at low SES Pakistani boys (as well as Black Caribbean boys) now appear to underachieve relative to White British students; at average SES this also includes Black African boys, and at high SES also Bangladeshi boys. Black Caribbean girls at average and high SES also now significantly underachieve. Thus the same factors that seem to account for the low attainment of White British low SES students relative to White British high SES students, and also most of the ethnic minority advantage over White British students at low SES, also reduce the attainment of ethnic minority boys, and Black Caribbean girls, below what might be expected given their parent, student, and school contexts, particularly at average and high levels of SES. This reflects the fact that ethnic minority groups are more advantaged on many of these parental and student variables relative to White British students ${ }^{\text {vi }}$ but, although these variables are strongly associated with attainment across the whole sample, they do not deliver the proportionately greater attainment for ethnic minority groups that would be expected.

\section{Educational progress age 11-16}

\section{Descriptive statistics}

By adding each student's prior attainment at age 11 the model addresses differences in educational progress age 11-16. Of the 15,028 students with valid ethnic group, gender, SES and GCSE results, 1,313 (8.7\%) had no age 11 test scores, including all 530 drawn from private schools where completion of national tests is optional. The total sample for the progress analysis was therefore 13,718. This sub-sample were slightly lower scoring at age 16 than the total sample (mean age 16 points score $=-.03 \mathrm{SD}$ ) but the difference was not statistically significant $(t=1.80, d f=655, p=.072)$ and so constitutes a representative sample of the full cohort in terms of age 16 outcomes. Table 7 presents descriptive statistics for age 11 , 14 and 16 scores for the prior attainment sample.

$<$ Insert Table 7 about here

Table 6 shows there were already significant differences related to ethnicity, gender and SES at age 11. The mean age 11 score for Pakistani students was -.44 SD below the mean for White British students, the means for Black Caribbean and Bangladeshi students were nearly one-third of a SD lower and the mean for Black African students was one-quarter of a SD 
below the mean for White British. SES differences were large with a gap of 1.27 SD between the bottom and top SES quintiles. There was a small but statistically significant gender difference of $0.07 \mathrm{SD}$. Clearly achievement gaps are of concern at the end of primary schooling at age 11 as well as at the end of statutory education at age 16.

Prior attainment is an extremely powerful predictor of later attainment (the correlation between students' age 11 test and age 16 exam scores was .69) so age 11 score can account for almost $50 \%$ of the variance in age 16 total points score. The final column of Table 7 presents the mean residuals from a student level simple linear regression of age 16 score on age 11 score, aggregated for each of the equity variables. This shows that SES gaps widens over the course of secondary school with students in the bottom SES quintile making -.21 SD less than expected progress and those in top quintile making .20 SD more than expected progress. The gender gap also widened with girls making significantly more progress than boys. In relation to ethnicity, all minority groups (except mixed heritage and Black Caribbean) made more progress than White British students. Indian students have pulled even further ahead of White British students by age 16, Bangladeshi and Black African students have eliminate the gap by age 16, and Pakistani students substantially close the gap, although a small gap at age 16 still remains. In contrast Black Caribbean students make no more progress than White British students, and their mean score remains -.30 SD below the White British average at age 16 . However because of the confounding between ethnicity and SES we again turn to multiple regression analysis to determine the net influences of ethnicity, gender and SES on student progress.

\section{Main effect and interaction models of progress (Models $1 \& 2$ )}

The results of the regression analyses modelling effects on progress are presented in Table 8. Model 1 present a simple main effects model of progress age 11-16 while simultaneously controlling for ethnic group, gender and SES. SES is strongly associated with progress with an SES coefficient of .21 SD, indicating a difference of .42 SD in progress between those students 1 SD below and those 1 SD above the mean SES. Girls also make more progress than boys (.18 SD) widening the gender gap. After control for SES and gender, apart from students of mixed heritage, all minority ethnic groups make significantly more progress than comparable White British students. While the improvement for Black Caribbean students is smaller than for other ethnic groups (.10 SD), after control for SES and gender they are on average making significantly more progress than comparable White British students. The analysis therefore suggest that White British students are the group making the least progress during secondary school after control for SES and gender. 
However, as with the analysis of attainment at age 16, there were strong and significant interactions between ethnicity, SES and gender, and additional significant interactions between ethnicity and prior attainment. After eliminating non-significant four-way, three-way and two-way interactions, three significant two-way interactions remained, all involving ethnicity. Model 2 presents the results. Significant ethnic by SES interactions for all ethnic groups (other than mixed heritage) indicate that the gap in progress between low and high SES students was significantly greater among White British students than for minority groups. The significant ethnic by gender interactions for Bangladeshi, Black Caribbean and Pakistani groups indicate the gender difference in favour of girls was significantly larger within these groups than among White British students. Finally the significant ethnic by age 11 score interactions for Black African and Black Caribbean students indicates the greater progress of these groups over White British students was substantially smaller among students with high prior attainment, indeed as we see below Black Caribbean boys of high prior attainment were notable as the only group to make less progress than comparable White British students.

Statistical tests were completed for ethnic contrasts at all levels of SES, gender and prior attainment. This generated a large number of contrasts so the results are best presented graphically as shown in Figure 5 (with the mean scores and statistically significant contrasts indicated in Appendix 1).

$<---$ Insert Figure 5 about here ---- >

The figure contain six panels (a-f) showing the relationships between ethnicity and SES for low (-1 SD), average and high (+1SD) levels of prior attainment and separately for boys and girls. The ethnic by SES interaction effects can be seen by the steeper SES gradient for White British students. This shows that the poorer progress for White British students relative to other ethnic groups was substantially greater among students from low SES backgrounds. The impact of the ethnic by gender interactions can be seen by comparing Panel (c) with Panel (d). The advantage of girls over boys is even greater in the Pakistani, Black Caribbean and Bangladeshi groups than among White British, indeed while Black Caribbean boys (of average SES and prior attainment) generally make the same progress as White British boys, Black Caribbean girls make greater progress than White British girls. These SES and gender features are also present among students of low prior attainment (Panels a \& b) and high prior attainment (Panels e \& f). However the contrast between White British and Black groups varies according to the level of prior attainment. In particular, evaluated at average SES, 
Black Caribbean girls made more progress than White British girls at low and average prior attainment but did not differ at high prior attainment, while Black Caribbean boys make more progress than White British students at low prior attainment, the same progress at average prior attainment and significantly less progress among students of high prior attainment.

In summary, the overall picture is that White British students make less progress age 11-16 than almost all other ethnic groups. This gap is most pronounced among students of low SES, with low SES White British students, particularly boys, generally making the least progress. The only group to make significantly less progress than their White British peers are Black Caribbean boys with high prior (age 11) attainment. At low SES these students make less progress than White British boys although this is not statistically significant (-.09 SD). However at average SES they make -.15 SD less progress, and at high SES -.22 SD less progress, than comparable White British boys (both $p<.0001$ ).

\section{Accounting for differential progress (Models 3-5)}

To explore whether these difference in educational progress can be explained by the contextual variables, Models 3, 4 and 5 add the parent, student and school variables described previously to create a contextual value added model.

Parental attitudes and behaviour: Parents' aspirations for the young person to continue in FTE after age 16 (.20 SD), providing a home computer (.22 SD), high parental involvement in school (.10 SD), parental monitoring of the child (.23 SD), a low frequency of quarrelling with children (.18 SD), a dual parent home (.13 SD) and providing private tuition (.07 SD) all have significant positive associations with student progress. These factors explain a significant amount of the SES effect (reduced from .46 to .30 SD) and can also account (statistically) for the greater progress of Bangladeshi students.

Student risk and protective factors: All the variables have a significant association with progress, most notably: students in the top band of academic self-concept make more progress (.28 SD) than those in the bottom band; students completing more homework make greater progress, ranging from .17 SD for those completing homework every weekday evening to $.10 \mathrm{SD}$ for those completing homework three evenings a week compared to none; Students with identified SEN make less progress (-.14 SD) than their peers without SEN; students who plan for the future make more progress (.05 SD) than those who do not plan; students ever excluded from school make less progress (-.27 SD) than those never excluded; students whose behaviour has led to the involvement of the police or social services make less progress (-.18 SD and -.32 SD if both); students who aspire to continue in FTE after the 
age of 16 make more progress (.11 SD), students who have had long term absence make less progress (-.22 SD); students who have truanted during the key stage make less progress (-.17 SD); and students in the top band for attitude to school make more progress (.14 SD) than those in the bottom band. These factors explain a significant amount of the SES effect (further reduced from .30 to $.20 \mathrm{SD}$ ) and reduce the gender gap still further (to .18 SD). They can also account (statistically) for the greater progress of Pakistani and Black African students.

School context: After accounting for all the above factors only school selective status had a significant effect, with students attending grammar schools making more progress (.13 SD) than comparable students attending comprehensive schools. There was no significant difference in progress between secondary modern and comprehensive schools.

Summary of contextual value added: The parental, student and school explanatory variables included in Model 5 account for more than half of the SES difference in student progress among White British students, reducing the contrast between high and low SES from .45 to .20 SD. Interestingly the size of the ethnic by SES interaction coefficients were substantially reduced, indicating the contextual factors were able to explain a large part of the particularly poor progress of low SES White British students (or equivalently the relatively greater progress of minority students from low SES backgrounds). Of the 17 contextual variables, particularly large WALD statistics were observed for student's educational aspirations, academic self concept, homework completion, truancy and school exclusion. These five factors alone (combined with gender) could explain $60 \%$ of the variance in progress (as opposed to $62.2 \%$ for all 17 variables).

The greater progress of girls is also reduced (from .17 to .10 SD) though girls still made better progress than boys and a gender by SES interaction indicates that girls from high SES backgrounds did particularly well relative to boys. With respect to ethnic group, Appendix 2 presents the mean age 16 scores by ethnicity, gender, SES and prior attainment after control for the contextual variables and can be compared to Appendix 1. Generally, even after control for the contextual variables, White British students made the least progress of all ethnic groups. However the size of the gaps were generally reduced substantially, and the contextual variables were able to account for the better progress of Bangladeshi, Pakistani and Black African boys (at mean prior attainment for all SES groups). The only group of students to make significantly less progress than White British students were Black Caribbean boys with high prior attainment (at all levels of SES) and those of average prior attainment at medium and high SES (all $p<.01$, see Appendix 2). The later result contrasts with the analysis 
before control for contextual factors, and indicates that we would expect more progress from Black Caribbean boys than is seen given the relative advantage of Black Caribbean students over White British students on the parental and student variables. So while White British pupils generally make the least progress, Black Caribbean boys of average or high prior attainment are particularly at risk for poor progress, whatever their level of SES.

\section{Progress by key stage}

The above analyses give a comprehensive view of differential progress age 11-16 and the interactions between ethnic group, SES, gender and prior attainment. However as a simplified mean of presenting the key ethnic group by SES interaction, and to help in identifying when during secondary schooling significant changes occur, it is also useful to present simple normalised mean scores at age 11, 14 and 16 for each ethnic group separately for the bottom, middle and upper SES quintiles (full results are given in Appendix 3). The results are clearly a simplification, ignoring as they do the ethnic by gender and ethnic by prior attainment interactions, but serve to illustrate the larger ethnic by SES interaction. For this purpose the age 16 core points score (based only on English, maths and science GCSE examinations) is used to maximise comparability with the age 11 and age 14 data which are based on English, mathematics and science tests. Figure5 presents the results graphically.

$$
<--- \text { Insert Figure } 5 \text { about here ---- > }
$$

Among the SES upper quintile, White British students maintain a high level of achievement across all time points. The ethnic gaps change little between age 11 and age 14 but close slightly at age 16. In the middle SES quintile, the pattern of ethnic differences is relatively consistent at age 11 and age 14, although Indian students have pulled ahead and Pakistani students have caught up substantially with White British students, but greater divergence emerges at age 16 with White British students showing a sharp decline while most minority groups show continued improvement (Bangladeshi students are an exception but this may reflect their relatively small numbers, see Appendix 3). The most marked contrasts in the ethnic profiles across time occur for the bottom SES quintile. Here a consistent decline for White British students is clearly manifest, from -.55 SD at age 11 to -.64 SD at age 14 and -.80 SD by age 16 . There are small changes at age 14 but it is age 16 that a radically different pattern of ethnic differentials emerge with White British students now the lowest achieving group and all minority groups are doing substantially better. The results identify the last two years of secondary school (Key Stage 4) as a key period for change. This will be discussed further below. 


\section{DISCUSSION}

What emerges from this analysis is a complicated picture of attainment differentiated by ethnic group, gender, SES and the interactions between these factors. Most research on ethnic group differences in educational attainment has treated SES as a control variable in simple additive models. This assumes, for example, that the 'effect' of gender or the 'effect' of SES is consistent across all ethnic groups. While some research has suggested that simple additive models are sufficient to reflect the relationship of attainment with ethnicity, gender and social class (e.g. Connolly, 2006; Rothon, 2007 $7^{\text {vii) }}$ these results support other research identifying significant interactions between these factors (e.g., Strand, 1999, 2010; Kingdon \& Cassen, 2010, Dekkers et al, 2000). In this context it makes no sense to draw simple comparisons between ethnic groups when the 'effect' of ethnicity depends on the level of other factors, such as gender or SES, indeed such comparisons can be highly misleading. For example, perhaps the most striking feature to emerge from this analysis is that the attainment of White British students is differentiated to a greater extent than any other ethnic group by SES. Low SES impacts negatively on attainment within all ethnic groups, but seem to be associated with disproportionately low attainment among White British students. At the same time, White British students from high SES backgrounds are among the highest attaining ethnic groups, with only Indian students scoring higher. Rather than treating White British students as an homogeneous group there is a need to recognise this high degree of polarisation around SES viii. As Evans (2010) argues "the relatively high attainment of white middle class children and young people has obscured the often chronically low achievement of the children of the poorest white working class families" (Evans, 2010, p3). A more illuminating approach may be to consider combinations of factors as defining groups whose educational progress and attainment is of particular concern. One of the main groups of concern in relation to low examination attainment at age 16 is White British working class students. Despite moral panics about white working class boys (Smith, 2010), it is apparent that this applies as much to White British working class girls, who are the lowest achieving group of girls, and to low SES Black Caribbean boys. However it is not all about class. A comprehensive analysis has also to account for the underachievement of Black Caribbean boys relative to their White British peers at average and high SES. Here the ethnic by gender interaction is also particularly important since we need to understand why Black Caribbean boys, but not Black Caribbean girls, underachieve relative to their White British peers.

In terms of student progress age 11-16 a similar pattern of results emerge. The main effects analysis suggested that, after controlling for SES and gender, White British students made less progress than all minority ethnic groups. However again the interaction terms indicate 
that the SES gap in progress was significantly larger for White British students than for minority groups, with an SES gap of .45 SD in terms of progress over the five years of secondary school. Figure 4 showed the substantial relative decline across ages 11, 14 and 16 of White British students in the lowest SES quintile. The gender gap also grows during secondary school for White British students with boys falling further behind girls, though the gender gap was even larger for both Black groups and Bangladeshi students. However the only group to make less progress than comparable White British students were more able Black Caribbean boys from average and high SES backgrounds. The very specific nature of this outcome demands close interpretation (see later).

\section{Ethnic minority resilience}

What factors account for the greater resilience to low SES among many minority ethnic groups compared to their similarly disadvantaged White British peers? One obvious difference between White British students and Indian, Pakistani, Bangladeshi and Black African students is the language factor ${ }^{\mathrm{ix}}$. However this factor might be assumed to have a negative, rather than a positive, association with attainment. Indeed the results reveal that having a first language other than English had a strong negative association with attainment at age 11 (-.50 SD), although by age 16 this reduced to -.17 SD and importantly was not substantial when all factors were included in the full contextual model ${ }^{x}$. It is likely that having a language other than English as a first/main language might account for some of the difference in attainment within minority ethnic groups, but relatively little of the difference between minority ethnic and White British groups.

The current research shows that most prominent among the factors that could account for the achievement gaps were parental and student educational aspirations to continue in FTE post 16, students academic self-concept (ASC), homework, truancy and exclusion. These factors could statistically account for the higher attainment and greater progress of most ethnic minority groups from low SES backgrounds, and were also able to account for the high achievement of Black Caribbean girls compared to boys. For example while only $60 \%$ of White British working class boys, $72 \%$ of Black Caribbean working class boys and $75 \%$ of White working class girls aspired to continue in FTE after 16, aspiration were uniformly high (95\% and above) across the SES spectrum for all other minority groups, including for Black Caribbean girls (Strand, 2008). Similar patterns were apparent for ASC, truancy and homework. These results indicate significant disengagement with education among White British working class students and Black Caribbean boys in particular, and similar results on the disengagement of low SES students have been reported by other authors (e.g. Ross, 2009). This offers encouragement in policy terms since these more proximal factors 
(educational aspirations, academic self concept, homework, truancy and so on) are easier to impact than the more structural factors underlying the SES variable. This does not indicate any 'quick fix' but it does indicate areas where intervention programmes might focus, earlier in students school careers, to have the best chance of impacting on achievement at age 16 .

Overall, these results chime with accounts that emphasise the importance of aspirational cultures among minority ethnic, particularly Asian, groups (e.g. Modood, 2003; Pearce \& Lin, 2007; Archer \& Francis, 2007). The 'immigrant paradigm' (Kao \& Tienda, 2003) suggests that immigrants devote themselves more to education than the native population because they lack financial capital and see education as a way out of poverty. In a similar vein, Ogbu (1978) made a distinction between 'voluntary minorities' (such as immigrant groups who may be recent arrivals to the country and have very high educational aspirations) and 'involuntary' or 'caste like' minorities (such as African Americans or Black Caribbean students in England) who have different orientations. These factors can impact at community not just individual level. A study by McLeod (1995) of two gangs of adolescent boys, one White, the other Black, both from the same deprived, inner city neighbourhood in the US, reports that the white teenagers showed the lowest aspirations and all came from families who had lived longest in the neighbourhood. Parents of the white boys were reticent in fostering high aspirations for their children; they saw them as unrealistic and did not want their children to experience disappointment, frustration and feelings of failure. By contrast, the parents of the black teenagers, all of whom were relatively recent arrivals in the neighbourhood, encouraged them to aspire to middle class values and norms. Thus McLeod (1995) suggests that those groups who have been located for longest within an area of social deprivation may feel more reluctant to embrace the educational aspirations that promise an escape from it. A recent initiative from the DCSF (2008) has also focussed on the problem of inter-generational poverty and low aspirations and attainment in deprived communities: "For the old working class security came from work: sons and daughters valued steady money and looked to leave school as soon as possible to find jobs, often through family contacts. In the heyday of heavy industry, this led many children into the same professions as their parents: the shipyard, the factory, the mine; unskilled jobs still offered security, but all that has changed" (p3). While a full discussion of 1419 educational reform is beyond the scope of this paper, the results have implications for policy, particularly regarding reforms to vocational provision in the curriculum as a means to motivate disaffected young people with more attractive and credible routes into further education and work ${ }^{\mathrm{xi}}$. 


\section{Ethnic minority underachievement}

There is however a paradox in this account. While controlling for variables such as educational aspirations, ASC, homework and truancy can explain the high achievement of minority ethnic groups at low SES, it simultaneously indicates under-achievement at average and high SES particularly for Pakistani, Black Caribbean, Black African and Bangladeshi boys, and also Black Caribbean girls (see Table 6). The analysis appears to 'over-correct', since average and high SES minority students are also more advantaged than their White British peers on many of these contextual factors and yet do not have higher achievement. Other factors must be involved. A particularly issue is why Black Caribbean boys from average and high SES backgrounds underachieve, even before the other family, student and school variables are taken into account. This may relate to the particularly poor progress of more able Black Caribbean boys from average and high SES backgrounds. This finding is consistent with previous research evaluating both progress from age 4 to age 7 (Strand, 1999) and in progress from age 7 to age 11 (Strand, 2010). It may be that teacher expectation effects are pertinent here, since Strand (2012) reports that Black Caribbean students are systematically under-represented in entry to higher tier examinations, even after controlling for prior attainment and a range other factors. This is likely to impact directly on the achievement and progress of the more able Black Caribbean students, but is also a window on wider teacher expectations for this ethnic group. It is also possible that this might be a 'peer group' effect if average and high SES Black Caribbean students are more likely to be exposed to disengaged peers at school. This may be a possibility since average and high SES Black Caribbean students attend schools where the whole school proportion of pupils entitled to FSM (24\%) is almost three times higher than the average for their middle/high SES White British peers (9\%). However there is no evidence that middle/high SES Black Caribbean students attend schools of lower quality than White British students of the same SES, since the school average age 11-16 value added (as calculated in school performance tables) did not differ significantly for middle/high SES Black Caribbean and White British students (999 and 997 respectively). Further research is needed to address this issue.

\section{Changes between age 14 and age 16}

Given the significant interactions reported here, an interesting question is why these interactions were not more prominent in a previous analysis of LSYPE data at age 14 (Strand, 2011). A reanalysis of the age 14 results, using the SES measure constructed here, did show statistically significant ethnic by SES interactions, but they were not nearly as marked as at age 16 so, for example, at age 14 Black Caribbean students significantly underperformed relative to White British students at all levels of SES. The ethnic by gender interactions were also not significant at age 14. Both these attest to the significant decline in achievement in the 
last two years of secondary school particularly for White British working class boys. To what extent might this reflect a differences in the measures of attainment between age 11/14 and public examinations at age 16 ? Kingdon and Cassen (2010) identify that ethnic minority groups have a higher rate of taking GNVQsii with $21 \%$ of White British students taking one or more GNVQs compared to $24 \%$ of Black African students, $25 \%$ of Black Caribbean, $26 \%$ of Indian, $30 \%$ of Pakistani and Bangladeshi students $32 \%$. They speculate that it could be easier to get good grades in GNVQs than in GCSE examinations. However this is not supported by the current finding that the advantage of minority ethnic groups is replicated with just the core points score for GCSEs in English, mathematics and science. Another significant difference at age 16 is the element of coursework in GCSE and assessment over a longer time period. Most minority ethnic groups report doing more homework and may also get more support from home with their studies. Also, in contrast to national tests at age 11/14, examinations at age 16 are 'high stakes' as they have a direct impact on students' employment prospects and/or entry to further education. This may focus attention and enhance family and wider support for minority students who are more aspirational and seeking to continue in full-time education, enter university and get on in the professions. Finally, we have used here measures of aspirations, attitudes and behaviours at age 14, but it is notable that analysis of later waves of the LSYPE identify low SES students are most likely to show negative change in aspirations and attitude to school between age 14 and age 16 (Goodman \& Gregg, 2010) so the results could also indicate a continued decline in aspirations and attitudes to school of White British working class students.

\section{Conclusion}

The study illustrates the complex nature of the interactions between ethnicity, gender, class and educational achievement at age 16. It suggests interpretations of educational success and failure based exclusively on social class, ethnicity or gender do not explain the complexity in the data. As Warikoo and Carter (2009) argue in a recent review "much of current research on race, ethnicity, culture and achievement relies on an additive, causal model rather than an intersectional model that exposes the complex and variable outcomes within different racial and ethnic groups" (p381). This does not mean that some elements of single explanations are invalid. For example the greater progress of White British high SES students may reflect the stronger access to social and economic capital exerted by high SES students (e.g. Reay, 2006), but class based explanations also need to be able to account for why average and high SES black students do not make similar progress to their White British peers. Equally the underachievement of average and high SES Black Caribbean boys may reflect factors within the school system such as teachers' low educational expectations or pervasive racism within the educational process (e.g. Gillborn, 2008), but such accounts also need to be able to 
explain why there is no significant Black Caribbean-White British gap in achievement among low SES boys, why Black Caribbean girls do as well or better than White British girls, and why Black African students show significantly greater achievement and progress than Black Caribbean students. These results challenge equity researchers to develop more nuanced accounts of educational success or failure, focussed on the intersections between ethnicity, gender and class. 


\section{References}

Archer, J., \& McDonald, M. (1991). Gender roles and school subjects in adolescent girls. Educational Research, 33(1), 55-64.

Archer, L., \& Francis, B. (2007). Understanding minority ethnic achievement: race, gender, class and 'success'. Abingdon: Routledge.

Beller, M., \& Gafni, N. (1996). The 1991 International assessment of educational progress in mathematics and sciences: The gender differences perspective. Journal of Educational Psychology, 88(2), 365-377.

Boudon, R. (1974). Education, opportunity and social inequality. New York: Wiley.

Bynner, J., \& Joshi, H. (2002). Equality and opportunity in education: Evidence from the 1958 and 1970 birth cohort studies. Oxford Review of Education, 28(4), 405-425.

Cheng, S., \& Starks, B. (2002). Racial differences in the effects of significant others on students educational aspirations. Sociology of Education, 75(4), 306-327

Coleman, J. S. (1966). Equality of educational opportunity. Washington: Office of Education, US Department of Health, Education and Welfare.

Connolly, P. (2006). The effects of social class and ethnicity on gender differences in GCSE Attainment: A secondary analysis of the youth cohort study of England and Wales 1997-2001. BERJ, 32, (1), 3-21. British Educational Research Journal, 32(1), 3-21.

DCSF. (2007). Gender and education: the evidence on pupils in England. London: Department for Children Schools and Families.

DCSF. (2008). The extra mile: How schools succeed in raising aspirations in deprived communities. Ref 00447-2008BKT-EN. London: Department for Schools, Children and Families.

DCSF. (2009). Deprivation and education: The evidence on pupils in England, Foundation Stage to Key Stage 4. London: Department for Children Schools and Families.

Demie, F. \& Lewis, K. (2011). White working class achievement: an ethnographic study of barriers to learning in schools. Educational Studies, 37, 245-264.

Dekkers, H., Bosker, R., \& Driessen, G. (2000). Complex inequalities of educational opportunities: A large scale longitudinal study on the relation between gender, social class, ethnicity and school success. Educational Research and Evaluation, 6(1), 5982.

Demack, S., Drew, D., \& Grimsley, M. (2000). Minding the gap: Ethnic, gender and social class differences in attainment at 16, 1988-95. Race, Ethnicity and Education, 3(2), 117-143.

DES (1985). Education for all. The report of the committee of enquiry into the education of children from ethnic minority groups (the Swann report). London: HMSO. 
DFE (2011). GCSE and equivalent attainment by pupil characteristics in England 2010/11.

Statistical First release SFR 03/2012. London: Department for Education.

DfES (2003). Pupil characteristics and class sizes in maintained schools in England, January 2003. SFR 09/2003. London: Department for Education and Skills. [Accessed 15/12/2011 from http://www.education.gov.uk/rsgateway/DB/SFR/s000390/sfro92003v2.pdf]

DfES (2006). Ethnicity and education. London: DfES. Available on the world wide web at: http://publications.teachernet.gov.uk/eOrderingDownload/DFES-0208-2006.pdf [accessed 27th June 2007).

Douglas, J. (1964). The home and the school: A study of ability and attainment in the primary school. London: MacGibbon \& Kee.

Dustmann, C., Machin, S., \& Schönberg, U. (2010). Ethnicity and Educational Achievement in Compulsory Schooling. The Economic Journal, 120(546), F272-F297

Evans, G. (2010). White working class underachievement: The pitfalls of targeted attainment strategies. Education Review, 22(2), 27-35.

Fryer, R. G., \& Levitt, S. D. (2004). Understanding the Black-White test score gap in the first two years of school. Review of Economics and Statistics, 86(2), 447-464.

Fryer, R. G., \& Levitt, S. D. (2006). The Black-White Test Score Gap Through Third Grade. American Law and Economics Review, 8(2), 249-281.

Gillborn, D. (2008). Racism and Education: Coincidence or conspiracy? Abingdon: Taylor \& Francis.

Gillborn, D., \& Mirza, H. (2000). Educational Inequality: Mapping Race, Class and Gender (HMI 232). London: OFSTED.

Goodman, A., \& Gregg, P. (2010). Poorer children's educational attainment: how important are attitudes and behaviour? York: Joseph Rowntree Foundation.

Jaccard, J., \& Turrisi, R. (2003). Interaction effects in multiple regression (second edition). Thousand Oaks: Sage.

Kao, G., \& Thompson, J. S. (2003). Racial and ethnic stratification in educational achievement and attainment. Annual Review of Sociology, 29(1), 417-442.

Kingdon, G., \& Cassen, R. (2010). Ethnicity and low achievement in English schools. British Educational Research Journal, 36(3), 403-431.

McIntosh, S., \& Vignoles, A. (2000). Measuring and Assessing the Impact of Basic Skills on Labour Market Outcomes. London: Centre for the Economics of Education.

Linting, M., Meulman, J. J., Groenen, P. J. F., \& van der Koojj, A. J. (2007). Nonlinear principal components analysis: Introduction and application. Psychological Methods, 12(3), 336-358. 
McLeod, J. (1995). Ain't no makin' it: Aspirations and attainment in a low income neighbourhood. Boulder, Colorado: Westview press.

McLoyd, V. C. (1998). Socioeconomic disadvantage and child development. American Psychologist, 53(2), 185-203.

Meulman, J., Van der Koou, A., \& Heiser, W. J. (2004). Principal components analysis with nonlinear optimal scaling transformations for ordinal and nominal data. In D. Kaplan (Ed.), The Sage handbook of quantitative methodology. Thousand Oaks: Sage.

Modood, T. (2003). Ethnic differentials in educational performance. In D. Mason (Ed.), Explaining ethnic differences. Bristol: The Policy press.

OECD. (2011). Education at a glance 2011: OECD Indicators: Organisation for Economic Cooperation and Development (OECD) publishing. available from the WWW at http:/dx.doi.org//10.1787/eag-2011-en [accessed 21/03/2012].

Ogbu, J. (1978). Minority education and caste. New York: Academic Press.

Payne, M. R. (2003). The differential impact of family characteristics on the academic achievement of black and white youth. Race and Society, 6(2), 141-162.

Pearce, R. R., \& Lin, Z. (2007). Chinese American post-secondary achievement and attainment: a cultural and structural analysis. Educational Review, 59(1), 19-36.

Phillips, M., Brooks-Gunn, J., Duncan, G., Klebanov, P., \& Crane, J. (1998). Family background, parenting practices, and the Black-White test score gap. In C. Jenks \& $M$. Phillips (Eds.), The Black-White test score gap (pp. 229-272). Washington DC: Brookings Institution Press.

Powdthavee, N., Levačic, R., \& Vignoles, A. (2006). The influence of family and social factors on educational attainment: a review of UK quantitative studies. London: Institute of Education.

Reay, D. (2006). The zombie stalking English schools: Social class and educational inequality. British Journal of Educational Studies, 54(3), 288-307.

Ross, A. (2009). Disengagement from education among 14-16 year olds. DCSF Research Report RR178. London: Department for Children, Schools and Families.

Rothon, C. (2007). Can achievement differentials be explained by social class alone? An examination of minority ethnic educational performance in England and Wales at the end of compulsory schooling. Ethnicities, 7(3), 306-322.

Sirin, S. R. (2005). Socioeconomic status and academic achievement: A meta-analytic review of research. . Review of Educational Research, 75(3), 417-453.

Smith, E. (2010). Underachievement, failing youth and moral panics. Evaluation \& Research in Education, 23(1), 37 - 49.

Spencer, N. (1996). Poverty and child health: Oxford: Medical Press. 
Støren, L. A., \& Helland, H. (2010). Ethnicity Differences in the Completion Rates of Upper Secondary Education: How Do the Effects of Gender and Social Background Variables Interplay? European Sociological Review, 26(5), 585-601

Strand, S. (1999). Ethnic group, sex and economic disadvantage: Associations with pupils' educational progress from Baseline to the end of Key Stage 1. British Educational Research Journal, 25, (2), 179-202.

Strand, S. (2008). Minority ethnic pupils in the Longitudinal Study of Young People in England: Extension report on performance in public examinations at age 16. DCSF Research Report RR-029. London: Department for Children, Schools and Families. Available online at: http://www.dfes.gov.uk/research/data/uploadfiles/DCSF-RR029.pdf

Strand, S. (2010). Do some schools narrow the gap? Differential school effectiveness by ethnicity, gender, poverty and prior attainment. School Effectiveness and School Improvement, 21(3), 289-314.

Strand, S. (2011). The limits of social class in explaining ethnic gaps in educational attainment. British Educational Research Journal, 37(2), 197-229.

Strand, S. (2012). The White British-Black Caribbean achievement gap: tests, tiers and teacher expectations. British Educational Research Journal, 38(1), 75-101.

Strand, S. \& J. Winston (2008). Educational aspirations in inner city schools. Educational Studies 34(4): 249-267.

Strand, S., De Coulon, A., Meschi, E., Vorhaus, J., Ivins, C., Small, L., . . Rehman, H. (2010). Drivers and challenges in raising the achievement of pupils from Bangladeshi, Somali and Turkish backgrounds (Research Report DCSF-RR226) London: Department for Children School and Families.

US Census Bureau (2006). Current population reports, p60-231, Income, poverty and health insurance in the United States 2005. US Government Printing Office: Washington DC. Retrieved from the www at http://www.census.gov/prod/2006pubs/p60-231.pdf on 7th July 2007.

Warikoo, N., \& Carter, P. (2009). Cultural Explanations for Racial and Ethnic Stratification in Academic Achievement: A Call for a New and Improved Theory. Review of Educational Research, 79(1), 366-394.

White, K. R. (1982). The relation between SES and academic achievement. Psychological Bulletin, 91, 461-481.

Wilson, D., Burgess, S., \& Briggs, A. (2011). The dynamics of school attainment of England's ethnic minorities. Journal of Population Economics, 24(2), 681-700. 
Table 1: $\quad$ Percentage of pupils achieving 5 or more GCSE or equivalent $A^{*}-C$ grades including English and mathematics by ethnic group and entitlement to FSM: England, 2011.

\begin{tabular}{lrrrr}
\hline Ethnic group & $\begin{array}{r}\text { Entitled to } \\
\text { FSM }\end{array}$ & $\begin{array}{r}\text { Not } \\
\text { entitled } \\
\text { FSM }\end{array}$ & $\begin{array}{r}\text { All } \\
\text { Students }\end{array}$ & $\begin{array}{r}\text { Percent- } \\
\text { age point } \\
\text { gap }\end{array}$ \\
\hline White British & 28.8 & 62.0 & 58.2 & 33.2 \\
Mixed heritage & 39.5 & 63.2 & 58.5 & 23.7 \\
Indian & 57.0 & 76.3 & 74.4 & 19.3 \\
Pakistani & 42.9 & 56.8 & 52.6 & 13.9 \\
Bangladeshi & 56.2 & 62.6 & 59.7 & 6.4 \\
Black African & 47.2 & 63.6 & 57.9 & 16.4 \\
Black Caribbean & 37.8 & 52.0 & 48.6 & 14.2 \\
Any Other group & 48.5 & 56.5 & 54.0 & 8.0 \\
\hline
\end{tabular}

Notes: Data taken from DFE (2011). Ethnic groups are the major groupings used in the LSYPE study. 
Table 2: $\quad$ Mean age 16 total points score by ethnic group, gender and socio-economic status (SES)

\begin{tabular}{|c|c|c|c|c|c|c|}
\hline \multirow[t]{2}{*}{ Variable and values } & \multirow[t]{2}{*}{$\begin{array}{l}\text { Un- } \\
\text { weighte } \\
\text { d count }\end{array}$} & \multicolumn{2}{|c|}{$\begin{array}{l}\text { Five or more GCSE } \\
\text { grades } A^{*}-C \text { (incl. } \\
\text { English \& maths) }\end{array}$} & \multicolumn{3}{|c|}{$\begin{array}{l}\text { Total points score } \\
\text { (Normalised) }\end{array}$} \\
\hline & & $\%$ & SE & Mean & & SE \\
\hline \multicolumn{7}{|l|}{ Ethnic group ${ }^{(a)}$} \\
\hline White British & 9879 & $47.6 \%$ & .009 & -.01 & & .019 \\
\hline Mixed heritage & 764 & $45.5 \%$ & .021 & -.02 & & .042 \\
\hline Indian & 1000 & $60.5 \%$ & .017 & .34 & $* * *$ & .039 \\
\hline Pakistani & 917 & $39.7 \%$ & .024 & -.09 & * & .036 \\
\hline Bangladeshi & 707 & $40.5 \%$ & .017 & -.07 & & .043 \\
\hline Black Caribbean & 553 & $30.4 \%$ & .019 & -.29 & $\star * *$ & .033 \\
\hline Black African & 583 & $41.8 \%$ & .022 & -.08 & & .043 \\
\hline Any other group & 625 & $55.1 \%$ & .020 & .27 & & .045 \\
\hline Gap (highest vs. lowest) & & $30.1 \%$ & & 0.63 & & \\
\hline \multicolumn{7}{|l|}{ Gender } \\
\hline Male & 7649 & $43.7 \%$ & .010 & -.11 & & .022 \\
\hline Female & 7417 & $51.6 \%$ & .010 & .11 & $* * *$ & .020 \\
\hline Gap & & $7.9 \%$ & & 0.23 & & \\
\hline \multicolumn{7}{|c|}{ Socio-Economic Status (SES) $^{(b)}$} \\
\hline Quintile 1 (lowest 20\%) & 4050 & $18.6 \%$ & 0.01 & -.65 & $* \star *$ & .021 \\
\hline Quintile 2 & 3141 & $32.1 \%$ & 0.01 & -.25 & $* * *$ & .021 \\
\hline Quintile 3 & 2793 & $46.4 \%$ & 0.01 & .00 & & .019 \\
\hline Quintile 4 & 2640 & $60.8 \%$ & 0.01 & .25 & $* * *$ & .019 \\
\hline Quintile 5 (highest 20\%) & 2404 & $80.2 \%$ & 0.01 & .66 & $* \star \star$ & .024 \\
\hline Gap (highest vs. lowest) & & $61.5 \%$ & & 1.31 & & \\
\hline Grand Mean ${ }^{(c)}$ & 15028 & $47.6 \%$ & 0.50 & 0.0 & & 1.00 \\
\hline
\end{tabular}

Notes: Data are weighted by combined design and non-response weights. ${ }^{\text {(a) }}$ ethic contrasts are against White British group. ${ }^{(b)}$ Quintiles are based on weighted SES scores, the unweighted $n$ reflects oversampling among deprived schools. When SES is modelled as a continuous variable the gap in age 16 points score between students $1 S D$ below the mean SES and those 1SD above the mean SES was 0.91. ${ }^{(c)}$ Values in the SE column are the standard deviation. $S E=$ standard error. ${ }^{*} p<.05 ;{ }^{* *} p<.01 ;$ *** p<.001. 
Table 3: Mean and distribution of SES by ethnic group

\begin{tabular}{|c|c|c|c|c|c|c|c|c|}
\hline \multirow[t]{2}{*}{ Ethnic group } & \multirow{2}{*}{$\begin{array}{r}\text { Mean } \\
\text { SES }\end{array}$} & \multirow{2}{*}{$\begin{array}{r}\text { Stan. } \\
\text { Err. }\end{array}$} & \multirow{2}{*}{$\begin{array}{r}\text { Un- } \\
\text { weight } \\
\text { ed } \mathrm{N}\end{array}$} & \multicolumn{5}{|c|}{ SES quintile } \\
\hline & & & & $\begin{array}{r}\text { Q1 } \\
\text { (low) }\end{array}$ & Q2 & Q3 & Q4 & $\begin{array}{r}\text { Q5 } \\
\text { (high) }\end{array}$ \\
\hline White British & .09 & .020 & 9879 & $17 \%$ & $19 \%$ & $21 \%$ & $22 \%$ & $21 \%$ \\
\hline Mixed heritage & -.22 & .045 & 764 & $27 \%$ & $21 \%$ & $17 \%$ & $17 \%$ & $17 \%$ \\
\hline Indian & -.20 & .040 & 1000 & $23 \%$ & $29 \%$ & $20 \%$ & $16 \%$ & $12 \%$ \\
\hline Pakistani & -.87 & .058 & 917 & $50 \%$ & $25 \%$ & $11 \%$ & $9 \%$ & $5 \%$ \\
\hline Bangladeshi & -1.67 & .050 & 707 & $79 \%$ & $14 \%$ & $4 \%$ & $2 \%$ & $1 \%$ \\
\hline Black Caribbean & -.56 & .036 & 553 & $32 \%$ & $32 \%$ & $22 \%$ & $9 \%$ & $5 \%$ \\
\hline Black African & -.87 & .061 & 583 & $49 \%$ & $20 \%$ & $14 \%$ & $10 \%$ & $7 \%$ \\
\hline Any other & -.47 & .051 & 625 & $34 \%$ & $23 \%$ & $15 \%$ & $13 \%$ & $15 \%$ \\
\hline Total & .00 & .000 & 15028 & $20 \%$ & $20 \%$ & $20 \%$ & $20 \%$ & $20 \%$ \\
\hline
\end{tabular}


Table 4: Multiple regression models for student attainment at age 16

\begin{tabular}{|c|c|c|c|c|c|c|c|c|c|c|c|}
\hline \multirow[b]{2}{*}{ Variable } & \multirow[b]{2}{*}{ Values } & \multicolumn{2}{|c|}{ Model1 } & \multicolumn{2}{|c|}{ Model 2} & \multicolumn{2}{|c|}{ Model 3} & \multicolumn{2}{|c|}{ Model 4} & \multicolumn{2}{|c|}{ Model 5} \\
\hline & & Coeff & SE & Coeff & SE & Coeff & SE & Coeff & SE & Coeff & SE \\
\hline Intercept & Intercept & -.161 & .017 & -.160 & .017 & -.992 & .040 & -.877 & .053 & -.833 & .057 \\
\hline Ethnic group & $\begin{array}{l}\text { Mixed heritage } \\
\text { Indian } \\
\text { Pakistani } \\
\text { Bangladeshi } \\
\text { Black Caribbean } \\
\text { Black African } \\
\text { Any other ethnic group }\end{array}$ & $\begin{array}{l}.118^{* *} \\
.500^{* * *} \\
.328^{* * *} \\
.671^{* * *} \\
.022^{* * *} \\
.335^{* * *}\end{array}$ & $\begin{array}{l}.037 \\
.036 \\
.032 \\
.050 \\
.032 \\
.041 \\
.039\end{array}$ & $\begin{array}{l}.185^{\star * *} \\
.461^{\star * *} \\
.190^{* \star *} \\
.208^{*} \\
.125^{\star *} \\
.199^{\star * *} \\
.430^{* * *}\end{array}$ & $\begin{array}{l}.050 \\
.043 \\
.050 \\
.085 \\
.047 \\
.058 \\
.056\end{array}$ & $\begin{array}{l}.103^{*} \\
.254^{* * *} \\
-.018^{*} \\
.022^{* * *} \\
-.225^{* *} \\
.005^{* * *}\end{array}$ & $\begin{array}{l}.048 \\
.041 \\
.050 \\
.082 \\
.050 \\
.053 \\
.052\end{array}$ & $\begin{array}{l}.056 \\
.063^{* *} \\
-.215^{\star * *} \\
-.175^{*} \\
-.231^{\star * *} \\
-.178^{\star * \star} \\
.158^{* * *}\end{array}$ & $\begin{array}{l}.045 \\
.037 \\
.042 \\
.078 \\
.042 \\
.052 \\
.045\end{array}$ & $\begin{array}{l}.060 \\
.069 \\
-.175^{* * *} \\
-.137^{* *} \\
-.204^{* *} \\
-.153^{* *} \\
.177^{* *}\end{array}$ & $\begin{array}{l}.045 \\
.036 \\
.041 \\
.087 \\
.044 \\
.050 \\
.044\end{array}$ \\
\hline Sex & Girls (vs. boys) & $.219^{* * *}$ & .016 & $.211^{* * *}$ & .017 & $.125^{* \star *}$ & .016 & $.060^{* * *}$ & .015 & $.085^{* * *}$ & .014 \\
\hline Socio-economic status & SES (normalised) & $.481^{* * *}$ & .010 & $.502 * * *$ & .011 & $.362^{* * *}$ & .011 & $.211^{* * *}$ & .012 & $.180^{* * *}$ & .011 \\
\hline Ethnic*SES & $\begin{array}{l}\text { Mixed heritage * SES } \\
\text { Indian * SES } \\
\text { Pakistani * SES } \\
\text { Bangladeshi * SES } \\
\text { Black Caribbean * SES } \\
\text { Black African * SES } \\
\text { Any other group * SES }\end{array}$ & & & $\begin{array}{l}-.057 \\
-.112^{* * *} \\
-.163^{* * *} \\
-.303^{* * *} \\
-.150^{* * *} \\
-.199^{* * *} \\
-.138^{* * *}\end{array}$ & $\begin{array}{l}.047 \\
.027 \\
.032 \\
.044 \\
.040 \\
.035 \\
.029\end{array}$ & $\begin{array}{l}-.059 \\
-.039 \\
-.130^{* * *} \\
-.220^{* * *} \\
-.110^{* *} \\
-.135^{* * *} \\
-.077^{* *}\end{array}$ & $\begin{array}{l}.045 \\
.027 \\
.032 \\
.043 \\
.037 \\
.032 \\
.028\end{array}$ & $\begin{array}{l}-.032 \\
.034 \\
-.073^{*} \\
-.171^{* \star *} \\
-.088^{* \star} \\
-.042 \\
.005\end{array}$ & $\begin{array}{l}.041 \\
.027 \\
.029 \\
.039 \\
.030 \\
.030 \\
.025\end{array}$ & $\begin{array}{l}-.038 \\
.006 \\
-.083^{\star *} \\
-.183^{* * *} \\
-.098^{\star * *} \\
-.066^{*} \\
-.001\end{array}$ & $\begin{array}{l}.040 \\
.027 \\
.029 \\
.044 \\
.029 \\
.029 \\
.025\end{array}$ \\
\hline Ethnic*Sex & $\begin{array}{l}\text { Mixed Heritage * girl } \\
\text { Indian * girl } \\
\text { Pakistani * girl } \\
\text { Bangladeshi * girl } \\
\text { Black Caribbean * girl } \\
\text { Black African * girl } \\
\text { Any Other * girl }\end{array}$ & & & $\begin{array}{l}-.135^{*} \\
.045 \\
.062 \\
.120^{*} \\
.164^{\star \star} \\
.005 \\
.104\end{array}$ & $\begin{array}{l}.067 \\
.052 \\
.049 \\
.060 \\
.058 \\
.063 \\
.078\end{array}$ & $\begin{array}{l}-.090 \\
.093 \\
.149^{* *} \\
.202^{\star * *} \\
.205^{\star * *} \\
.055 \\
.133\end{array}$ & $\begin{array}{l}.062 \\
.050 \\
.048 \\
.061 \\
.059 \\
.058 \\
.075\end{array}$ & $\begin{array}{l}-.031 \\
.156^{* \star *} \\
.220^{* * *} \\
.293^{* * *} \\
.088^{*} \\
.127^{*} \\
.156^{*}\end{array}$ & $\begin{array}{l}.057 \\
.045 \\
.045 \\
.058 \\
.057 \\
.057 \\
.068\end{array}$ & $\begin{array}{l}-.039^{*} .161^{\star \star *} \\
.230^{\star * *} \\
.307^{\star * *} \\
.066^{\star} \\
.115^{\star} \\
.124^{*}\end{array}$ & $\begin{array}{l}.056 \\
.044 \\
.046 \\
.059 \\
.056 \\
.055 \\
.065\end{array}$ \\
\hline $\begin{array}{l}\text { Family composition } \\
\text { Computer } \\
\text { Private tuition } \\
\text { Parental involvement } \\
\text { (base= none) } \\
\text { Parental monitoring } \\
\text { Parental aspiration } \\
\text { Family discord } \\
\text { (base=< once a week) }\end{array}$ & $\begin{array}{l}\text { Single parent family (vs. dual parent) } \\
\text { Home computer for student use } \\
\text { Private tuition in NC subjects } \\
1-2 \text { school activities } \\
3+\text { school activities } \\
\text { Always knows where YP is when out } \\
\text { YP continue in FTE after age } 16 \\
\text { Parent reported arguining most days } \\
\text { Parent reported arguing > once a week }\end{array}$ & & & & & $\begin{array}{l}-.110^{* * *} \\
.365^{* * *} \\
.044^{*} \\
.034^{* * *} \\
.137^{* * *} \\
.260^{* * *} \\
.515^{* * *} \\
-.294^{* * *} \\
-.140^{* * *}\end{array}$ & $\begin{array}{l}.016 \\
.021 \\
.020 \\
.032 \\
.038 \\
.017 \\
.016 \\
.019 \\
.014\end{array}$ & $\begin{array}{l}-.058^{* * *} \\
.209^{* * *} \\
.033^{*} \\
-.015^{-058^{* *}} \\
.078^{* * *} \\
.200^{* * *} \\
-.124^{* * *} \\
-.070^{* * *}\end{array}$ & $\begin{array}{l}.013 \\
.018 \\
.017 \\
.030 \\
.034 \\
.015 \\
.014 \\
.016 \\
.013\end{array}$ & $\begin{array}{l}-.062^{* * *} \\
.209^{* * *} \\
.027^{*} \\
-.014^{*} \\
.042^{* * *} \\
.075^{* * *} \\
.184^{* *} \\
-.120^{* *} \\
-.070^{* * *}\end{array}$ & $\begin{array}{l}.013 \\
.018 \\
.017 \\
.029 \\
.034 \\
.015 \\
.013 \\
.016 \\
.012\end{array}$ \\
\hline
\end{tabular}


SEN

Truancy

Absence (long term)

Service involvement

\section{Excluded}

Student aspiration

Student planning

(base $=$ very high)

\section{Homework}

(base=none)

Academic Self Concept
(base $=$ very low)
Attitude to school
(base = very low)
Girl * SES

School deprivation

Selective schools

(base=comprehensive)

School type quintile (base $=<5 \%$ )

(base=community)
School action plus or statemented

Anytime (Y7-Y9)

Absence $>1$ month in $Y 9$

Police and Social Service/EWS

Police or Social Services/EWS

Excluded anytime Y7-Y9

Continue in FTE after age 16

Very low

Low

High

1 evening a week

2 evenings a week

3 evenings a week

4 evenings a week

5 evenings a week

Very high

High

Low

Very high

High

Low

Girl * SES

School \%FSM 35\%

$\%$ FSM $21 \%-35 \%$

$\%$ FSM $13 \%-21 \%$

$\%$ FSM $9 \%-13 \%$

$\%$ FSM 5\%-9\%

Secondary modern

Grammar

Church school

Foundation school

\begin{tabular}{|c|c|c|c|}
\hline$-.581^{* * *}$ & .033 & $-.555^{* * *}$ & .029 \\
\hline$-.157^{\star * *}$ & .017 & $-.155^{* * *}$ & .017 \\
\hline$-.257^{* * *}$ & .032 & $-.249 * * *$ & .032 \\
\hline$-.345^{* * *}$ & .042 & $-.336 * * *$ & .042 \\
\hline$-.197^{\star \star *}$ & .018 & $-.190 * * *$ & .018 \\
\hline$-.255^{* * *}$ & .021 & $-.259 * * *$ & .021 \\
\hline $.218^{* * *}$ & .014 & $.206^{\star * *}$ & .014 \\
\hline$-.202^{* * *}$ & .021 & $-.199 * * *$ & .021 \\
\hline$-.161^{\star \star \star}$ & .020 & $-.161^{\star * *}$ & .019 \\
\hline$-.043^{* * *}$ & .013 & $-.045^{* * *}$ & .012 \\
\hline .041 & .032 & .041 & .031 \\
\hline $.080^{\star \star}$ & .030 & $.071^{\star}$ & .030 \\
\hline $.199^{\star \star \star}$ & .031 & $.178^{\star \star \star}$ & .031 \\
\hline $.281^{\star * *}$ & .034 & $.227^{\star \star *}$ & .033 \\
\hline $.311^{\star \star \star \star}$ & .034 & $.226 * * *$ & .033 \\
\hline $.661^{* * *}$ & .023 & $.681^{\star * \star}$ & .022 \\
\hline $.403^{\star \star \star}$ & .019 & $.417^{* * *}$ & .018 \\
\hline $.164^{\star \star \star *}$ & .017 & $.174^{\star \star *}$ & .017 \\
\hline .020 & .016 & .027 & .016 \\
\hline $.059^{\star \star \star}$ & .016 & $.067^{\star \star \star \star}$ & .016 \\
\hline .046 ** & .015 & $.046^{\star \star}$ & .014 \\
\hline \multirow[t]{10}{*}{$.058^{* * *}$} & .014 & $.063^{* * *}$ & .014 \\
\hline & & $-.180^{\star * *}$ & .037 \\
\hline & & -.065 & .039 \\
\hline & & -.067 & .037 \\
\hline & & -.068 * & .033 \\
\hline & & -.052 & .028 \\
\hline & & $-.103^{* *}$ & .037 \\
\hline & & $.575^{* * *}$ & .064 \\
\hline & & $.083^{* *}$ & .030 \\
\hline & & .032 & .027 \\
\hline
\end{tabular}

$\mathrm{R} 2$

$23.7 \%$

$24.0 \%$

$32.4 \%$

$49.7 \%$

$51.3 \%$

\section{Notes}

Sample size is 15028 for all models. Increase in R2 for Model 2 over Model 1 is statistically significant $(p<.001) .{ }^{*} p<.05 ;{ }^{* *} p<.01 ;{ }^{* * *} p<.001$ 
Table 5: Age 16 points score by ethnic group, gender and SES (Model 2)

\begin{tabular}{|c|c|c|c|c|c|c|c|}
\hline \multirow[b]{3}{*}{ Sex } & \multirow[b]{3}{*}{ Ethnic group } & \multicolumn{3}{|c|}{ Mean Age 16 score } & \multicolumn{3}{|c|}{ Difference from White British } \\
\hline & & \multicolumn{3}{|c|}{ SES } & \multicolumn{3}{|c|}{ SES } \\
\hline & & $-1 S D$ & Mean & $+1 S D$ & $-1 S D$ & Mean & $+1 S D$ \\
\hline \multirow[t]{8}{*}{ Boys } & White British & -0.50 & 0.00 & 0.50 & - & & \\
\hline & Mixed heritage & -0.26 & 0.18 & 0.63 & $0.24++$ & $0.18++$ & 0.13 \\
\hline & Indian & 0.07 & 0.46 & 0.85 & $0.57++$ & $0.46++$ & $0.35++$ \\
\hline & Pakistani & -0.15 & 0.19 & 0.53 & $0.35++$ & $0.19++$ & 0.03 \\
\hline & Bangladeshi & 0.01 & 0.21 & 0.41 & $0.51++$ & $0.21+$ & -0.10 \\
\hline & Black Caribbean & -0.48 & -0.13 & 0.23 & 0.02 & $-0.13--$ & $-0.27--$ \\
\hline & Black African & -0.10 & 0.20 & 0.50 & $0.40++$ & $0.20++$ & 0.00 \\
\hline & Any other group & 0.07 & 0.43 & 0.79 & $0.57++$ & $0.43++$ & $0.29++$ \\
\hline \multirow[t]{8}{*}{ Girls } & White British & -0.29 & 0.21 & 0.71 & - & - & - \\
\hline & Mixed heritage & -0.18 & 0.26 & 0.71 & 0.11 & 0.05 & -0.01 \\
\hline & Indian & 0.33 & 0.72 & 1.11 & $0.62++$ & $0.51++$ & $0.39++$ \\
\hline & Pakistani & 0.12 & 0.46 & 0.80 & $0.42++$ & $0.25++$ & 0.09 \\
\hline & Bangladeshi & 0.34 & 0.54 & 0.74 & $0.63++$ & $0.33++$ & 0.02 \\
\hline & Black Caribbean & -0.10 & 0.25 & 0.60 & $0.19++$ & 0.04 & -0.11 \\
\hline & Black African & 0.11 & 0.42 & 0.72 & $0.40++$ & $0.20++$ & 0.00 \\
\hline & Any other group & 0.38 & 0.75 & 1.11 & $0.67++$ & $0.53++$ & $0.40++$ \\
\hline
\end{tabular}

Notes: The reference category is White British, boys at mean SES $(0.00)$ and all estimates are relative to this base group. The model includes just ethnic group, gender and SES. The significance tests compare each ethnic group to White British pupils within each SES and gender combination. A plus sign (+) indicates the group scored significantly higher than White British, while a negative sign (-) indicates the group scored significantly lower than White British $(-/+=p<.05,--/++=p<.01)$.

Table 6: Age 16 points score by ethnic group, gender and SES after controls (Model 5)

\begin{tabular}{|c|c|c|c|c|c|c|c|}
\hline \multirow[b]{3}{*}{ Sex } & \multirow[b]{3}{*}{ Ethnic group } & \multicolumn{3}{|c|}{ Mean age 16 score } & \multicolumn{3}{|c|}{ Difference from White British } \\
\hline & & \multicolumn{3}{|c|}{ SES } & \multicolumn{3}{|c|}{$\begin{array}{c}\text { SES } \\
\end{array}$} \\
\hline & & $-1 \mathrm{SD}$ & Mean & $+1 S D$ & $-1 \mathrm{SD}$ & Mean & $+1 \mathrm{SD}$ \\
\hline \multirow[t]{8}{*}{ Boys } & White British & -0.18 & 0.00 & 0.18 & - & - & - \\
\hline & Mixed heritage & -0.08 & 0.06 & 0.20 & 0.10 & 0.06 & 0.02 \\
\hline & Indian & -0.12 & 0.07 & 0.26 & 0.06 & 0.07 & 0.08 \\
\hline & Pakistani & -0.27 & -0.18 & -0.08 & $-0.09--$ & $-0.18-$ & $-0.26--$ \\
\hline & Bangladeshi & -0.13 & -0.14 & -0.14 & 0.05 & -0.14 & $-0.32--$ \\
\hline & Black Caribbean & -0.29 & -0.20 & -0.12 & $-0.11-$ & $-0.20-$ & $-0.30--$ \\
\hline & Black African & -0.27 & -0.15 & -0.04 & -0.09 & $-0.15-$ & $-0.22--$ \\
\hline & Any other group & 0.00 & 0.18 & 0.36 & $0.18++$ & $0.18+$ & $0.18++$ \\
\hline \multirow[t]{8}{*}{ Girls } & White British & -0.16 & 0.09 & 0.33 & - & - & - \\
\hline & Mixed heritage & -0.10 & 0.11 & 0.31 & 0.06 & 0.02 & -0.02 \\
\hline & Indian & 0.07 & 0.32 & 0.57 & $0.22++$ & $0.23+$ & $0.24++$ \\
\hline & Pakistani & -0.02 & 0.14 & 0.30 & 0.14 & 0.05 & -0.03 \\
\hline & Bangladeshi & 0.19 & 0.26 & 0.32 & $0.35++$ & 0.17 & -0.01 \\
\hline & Black Caribbean & -0.20 & -0.05 & 0.09 & -0.04 & $-0.14-$ & $-0.24--$ \\
\hline & Black African & -0.13 & 0.05 & 0.22 & 0.03 & -0.04 & -0.10 \\
\hline & Any other group & 0.14 & 0.39 & 0.63 & $0.30++$ & $0.30+$ & $0.30++$ \\
\hline
\end{tabular}

Notes: As per Table 4, except the model controls for all family, student and school variables as shown in Table 3. 
Table 7: Mean and SE for age 11, age 14 and age 16 outcomes by ethnic group, gender and SES for the prior attainment sample

\begin{tabular}{|c|c|c|c|c|c|c|c|c|c|c|c|c|}
\hline \multirow[t]{2}{*}{ Variable and values } & \multirow[t]{2}{*}{$\begin{array}{r}\text { Un- } \\
\text { weighted } \\
\text { count }\end{array}$} & \multicolumn{2}{|c|}{$\begin{array}{l}\text { Age } 11 \text { Level } 4 \\
\text { or above in } \\
\text { English \& maths }\end{array}$} & \multicolumn{2}{|c|}{$\begin{array}{c}\text { Age } 11 \text { average } \\
\text { test marks } \\
\text { (Normalised) }\end{array}$} & \multicolumn{3}{|c|}{$\begin{array}{c}\text { Age } 14 \text { average } \\
\text { test marks } \\
\text { (Normalised) }\end{array}$} & \multicolumn{2}{|c|}{$\begin{array}{l}\text { Age } 16 \text { total } \\
\text { points score } \\
\text { (Normalised) }\end{array}$} & \multicolumn{2}{|c|}{$\begin{array}{l}\text { Pure progress } \\
\text { age } 11-16 \\
\text { (residuals) }\end{array}$} \\
\hline & & $\%$ & SE & Mean & $\mathrm{SE}$ & Mean & & SE & Mean & SE & Mean & SE \\
\hline \multicolumn{13}{|l|}{ Ethnic group ${ }^{(a)}$} \\
\hline White British & 9149 & $66.6 \%$ & .01 & .08 & .02 & .09 & & .02 & -.04 & .02 & -.03 & .03 \\
\hline Mixed heritage & 705 & $65.6 \%$ & .02 & .05 & .04 & .07 & & .04 & -.06 & .04 & -.04 & .03 \\
\hline Indian & 950 & $67.8 \%$ & .01 & .03 & .04 & .17 & & .04 & $.33 * * *$ & .04 & $.37^{\star * *}$ & .03 \\
\hline Pakistani & 855 & $50.0 \%$ & .02 & $-.44 * * *$ & .03 & -.34 & $* * *$ & .03 & $-.12 *$ & .03 & $.23^{* * *}$ & .03 \\
\hline Bangladeshi & 647 & $55.3 \%$ & .02 & $-.29 * * *$ & .04 & -.27 & $* * *$ & .04 & -.02 & .04 & $.24 * * *$ & .04 \\
\hline Black Caribbean & 501 & $48.9 \%$ & .02 & $-.32 * * *$ & .04 & -.37 & $* * *$ & .04 & $-.30 * * *$ & .03 & -.02 & .03 \\
\hline Black African & 415 & $54.6 \%$ & .02 & $-.26^{* * *}$ & .05 & -.17 & $* * *$ & .05 & .01 & .05 & $.25 * * *$ & .04 \\
\hline Any other group & 496 & $60.4 \%$ & .02 & .01 & .05 & .17 & & .05 & $.23 * * \star$ & .05 & $.28 * * *$ & .04 \\
\hline Gap (White British vs. lowest minority) & & $18.9 \%$ & & 0.51 & & 0.46 & & & 0.26 & & .01 & \\
\hline \multicolumn{13}{|l|}{ Gender } \\
\hline Male & 6959 & $63.0 \%$ & .01 & .01 & .02 & .02 & & .02 & -.13 & .02 & -.09 & .01 \\
\hline Female & 6759 & $68.2 \%$ & .01 & $.08 * * *$ & .02 & .13 & *** & .02 & $.09 * * *$ & .02 & $.09 * * *$ & .01 \\
\hline Gap & & $5.2 \%$ & & 0.07 & & 0.11 & & & 0.22 & & 0.17 & \\
\hline \multicolumn{13}{|l|}{ Socio-Economic Status (SES) ${ }^{(\mathbf{b})}$} \\
\hline Quintile 1 (lowest 20\%) & 3685 & $42.5 \%$ & .01 & $-.53^{\star * *}$ & .02 & -.59 & *** & .02 & $-.63^{* * *}$ & .02 & $-.21^{* * *}$ & .02 \\
\hline Quintile 2 & 2953 & $57.5 \%$ & .01 & $-.19 * * *$ & .02 & -.20 & *** & .02 & $-.24 * * *$ & .02 & $-.05 * * *$ & .02 \\
\hline Quintile 3 & 2631 & $67.9 \%$ & .01 & .07 & .02 & .09 & & .02 & -.02 & .02 & -.01 & .01 \\
\hline Quintile 4 & 2435 & $76.7 \%$ & .01 & $.30 * * *$ & .02 & .36 & *** & .02 & $.25 * * *$ & .02 & $.10^{* * *}$ & .02 \\
\hline Quintile 5 (highest 20\%) & 2014 & $87.4 \%$ & .01 & $.72^{\star \star *}$ & .02 & .85 & *** & .03 & $.64^{* \star *}$ & .02 & .20 *** & .02 \\
\hline Gap (top vs. bottom quintile) & & $44.9 \%$ & & 1.25 & & 1.43 & & & 1.27 & & 0.41 & \\
\hline Grand Mean ${ }^{(\mathrm{c})}$ & 13718 & $65.6 \%$ & 0.48 & 0.05 & 1.0 & .08 & & 1.0 & -0.03 & 1.0 & 0.00 & 1.0 \\
\hline
\end{tabular}

Notes: Data are weighted by combined design and non-response weights. ${ }^{(a)}$ Contrasts with White British ${ }^{\text {(b) }}$ SES quintiles are based on weighted SES

scores, the unweighted $n$ reflects oversampling among deprived schools. ${ }^{(c)}$ Values in the $S E$ column are the standard deviation. $S E=$ standard error. ${ }^{*} p<.05$;

${ }^{* *} p<.01 ;{ }^{* * *} p<.001$ 
Table 8: Multiple regression models for student progress age 11 - 16

\begin{tabular}{|c|c|c|c|c|c|c|c|c|c|c|c|}
\hline \multirow[b]{2}{*}{ Variable } & \multirow[b]{2}{*}{ Values } & \multicolumn{2}{|c|}{ Model 1} & \multicolumn{2}{|c|}{ Model 2} & \multicolumn{2}{|c|}{ Model 3} & \multicolumn{2}{|c|}{ Model 4} & \multicolumn{2}{|c|}{ Model 5} \\
\hline & & Coeff & SE & Coeff & SE & Coeff & SE & Coeff & SE & Coeff & SE \\
\hline Intercept & Intercept & -.174 & .013 & -.171 & .013 & -.641 & .034 & -.604 & .049 & -.608 & .052 \\
\hline \multirow[t]{7}{*}{ Ethnic group } & Mixed heritage & .051 & .030 & $.118^{\star *}$ & .043 & $.087^{*}$ & .042 & $.089 *$ & .041 & $.090 *$ & .040 \\
\hline & Indian & $.457^{* \star *}$ & .029 & $.426^{\star \star *}$ & .034 & $.295^{* \star *}$ & .034 & $.174^{\star \star *}$ & .033 & $.175^{* \star *}$ & .034 \\
\hline & Pakistani & $.414^{* \star *}$ & .028 & $.283^{* \star *}$ & .039 & $.147^{\star \star \star}$ & .040 & .024 & .036 & .029 & .036 \\
\hline & Bangladeshi & $.539^{* * *}$ & .039 & $.220 * \star$ & .076 & .082 & .070 & -.061 & .075 & -.053 & .080 \\
\hline & Black Caribbean & $.101^{\star \star \star}$ & .027 & -.033 & .035 & $-.073^{*}$ & .036 & -.090 ** & .032 & -.094 ** & .034 \\
\hline & Black African & $.394^{* \star *}$ & .040 & $.307^{\star * *}$ & .061 & $.205^{\star * *}$ & .057 & .077 & . 048 & .067 & .048 \\
\hline & Any other ethnic group & $.418^{* \star \star}$ & .036 & $.310^{* * *}$ & .050 & $.234^{\star \star \star}$ & .048 & $.174^{\star \star *}$ & . 045 & $.174^{\star \star *}$ & .044 \\
\hline Sex & Girls (vs. boys) & $.178^{* \star *}$ & .011 & $.171^{\star \star *}$ & .012 & $.132^{* * *}$ & .012 & $.093^{* * *}$ & .011 & $.099^{* * *}$ & .011 \\
\hline Socio-economic status & SES (normalised) & $.213^{* \star *}$ & .008 & $.226^{* \star \star}$ & .011 & $.152^{\star \star \star}$ & .012 & $.102^{\star \star \star}$ & .011 & $.097^{\star \star \star}$ & .010 \\
\hline Age 11 score & Age 11 score (normalised) & $.609 * \star \star$ & .007 & $.611^{\star \star \star}$ & .008 & $.572^{\star \star \star}$ & .008 & $.474^{\star \star \star}$ & .008 & $.465^{* * *}$ & .008 \\
\hline \multirow[t]{7}{*}{ Ethnic ${ }^{*}$ SES } & Mixed heritage * SES & & & .009 & .036 & -.007 & .036 & .006 & .035 & .009 & .035 \\
\hline & Indian * SES & & & $-.082^{* \star *}$ & .023 & -.046 & .024 & -.021 & .023 & -.025 & .023 \\
\hline & Pakistani * SES & & & $-.100 * \star$ & .030 & -.084 *夫 & .030 & $-.054 *$ & .027 & $-.053^{*}$ & .027 \\
\hline & Bangladeshi * SES & & & $-.153^{\star * \star}$ & .039 & $-.109 * \star$ & .037 & $-.106^{\star *}$ & .039 & $-.106 * *$ & .040 \\
\hline & Black Caribbean * SES & & & $-.065 *$ & .031 & $-.061^{*}$ & .030 & -.040 & .028 & -.041 & .028 \\
\hline & Black African * SES & & & $-.101^{\star \star}$ & .038 & -.070 & .036 & -.025 & .035 & -.031 & .035 \\
\hline & Any other group * SES & & & $-.177^{\star \star \star}$ & .032 & $-.133^{\star \star *}$ & .030 & $-.091^{\star \star \star}$ & .028 & $-.091^{\star \star *}$ & .027 \\
\hline \multirow[t]{7}{*}{ Ethnic*Sex } & Mixed Heritage * girl & & & $-.118 *$ & .058 & -.076 & .056 & -.039 & .052 & -.046 & .051 \\
\hline & Indian * girl & & & .028 & .036 & .050 & .036 & $.074 *$ & .036 & $.077^{*}$ & .037 \\
\hline & Pakistani * girl & & & $.123^{\star *}$ & .041 & $.155^{\star * \star}$ & .041 & $.199^{\star \star \star}$ & .039 & $.202^{\star \star \star}$ & .039 \\
\hline & Bangladeshi * girl & & & $.205^{\star \star \star}$ & .055 & $.242^{\star \star \star}$ & .054 & $.290^{\star \star \star}$ & .054 & $.291^{\star \star \star}$ & .055 \\
\hline & Black Caribbean * girl & & & $.143^{\star *}$ & .048 & $.166^{* \star \star}$ & .047 & $.111 *$ & .043 & $.107^{\star}$ & .044 \\
\hline & Black African * girl & & & .009 & .068 & .020 & .063 & .072 & .055 & .070 & .055 \\
\hline & Any Other * girl & & & .065 & .066 & .065 & .064 & .080 & .061 & .071 & .059 \\
\hline Sex * SES & Sex*SES & & & .007 & 012 & .012 & 012 & $.038^{* * *}$ & .011 & $.040^{\star \star \star}$ & .011 \\
\hline \multirow[t]{7}{*}{ Ethnic * Age 11 score } & Mixed Heritage * age 11 & & & -.030 & .027 & -.019 & .027 & -.030 & .028 & -.035 & .027 \\
\hline & Indian * age 11 & & & .031 & .023 & $.056 *$ & .023 & $.088^{\star * \star}$ & .022 & $.084^{\star * *}$ & .022 \\
\hline & Pakistani * age 11 & & & -.006 & .023 & .020 & .023 & $.051^{\star}$ & .023 & $.055^{*}$ & .023 \\
\hline & Bangladeshi ${ }^{*}$ age 11 & & & $-.058^{*}$ & .029 & -.030 & .028 & -.008 & .029 & -.007 & .030 \\
\hline & Black Caribbean * age 11 & & & $-.122 * \star \star$ & .028 & $-.108^{\star \star \star}$ & .028 & $-.084^{\star \star}$ & .026 & $-.083^{\star \star}$ & .026 \\
\hline & Black African * age 11 & & & $-.100 * * *$ & .029 & $-.086^{\star \star}$ & .027 & -.055 & .029 & -.055 & .029 \\
\hline & Any other * age 11 & & & -.011 & .031 & -.008 & .030 & .030 & .028 & .028 & .028 \\
\hline
\end{tabular}


Table 9: Multiple regression models for student progress age 11 - 16 (Continued)

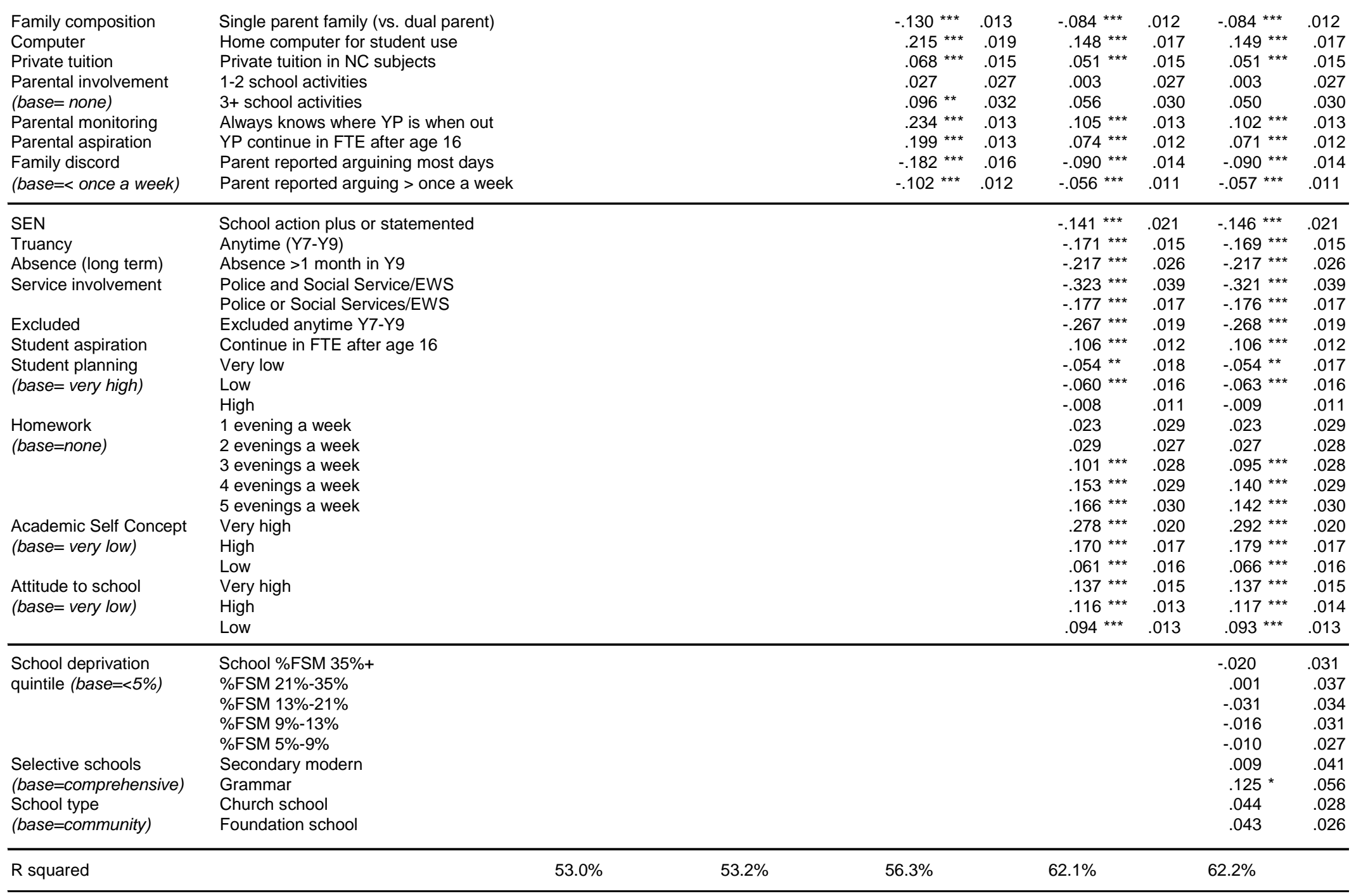

Notes: Sample size is 15028 for all models. Increase in $R^{2}$ for Model 2 over Model 1 is statistically significant $(p<.001) .{ }^{*} p<.05 ;{ }^{* *} p<.01 ;{ }^{* * *} p<.001$ 
Figure 1: $\quad$ Percentage of pupils achieving 5 or more GCSE or equivalent $A^{*}-C$ grades including English and mathematics by ethnic group and entitlement to FSM: England, 2011

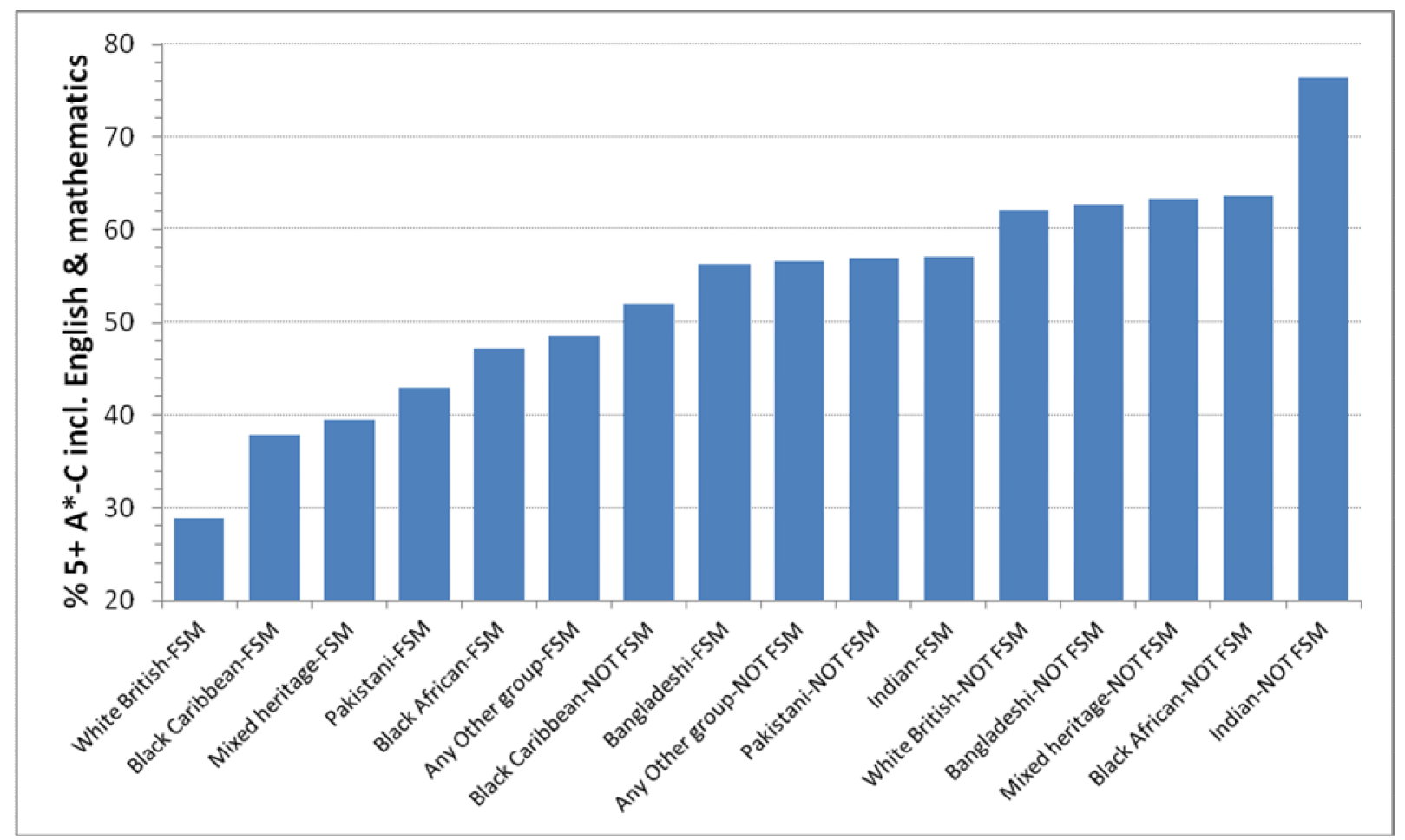

Figure 2: SES quintiles by ethnic group

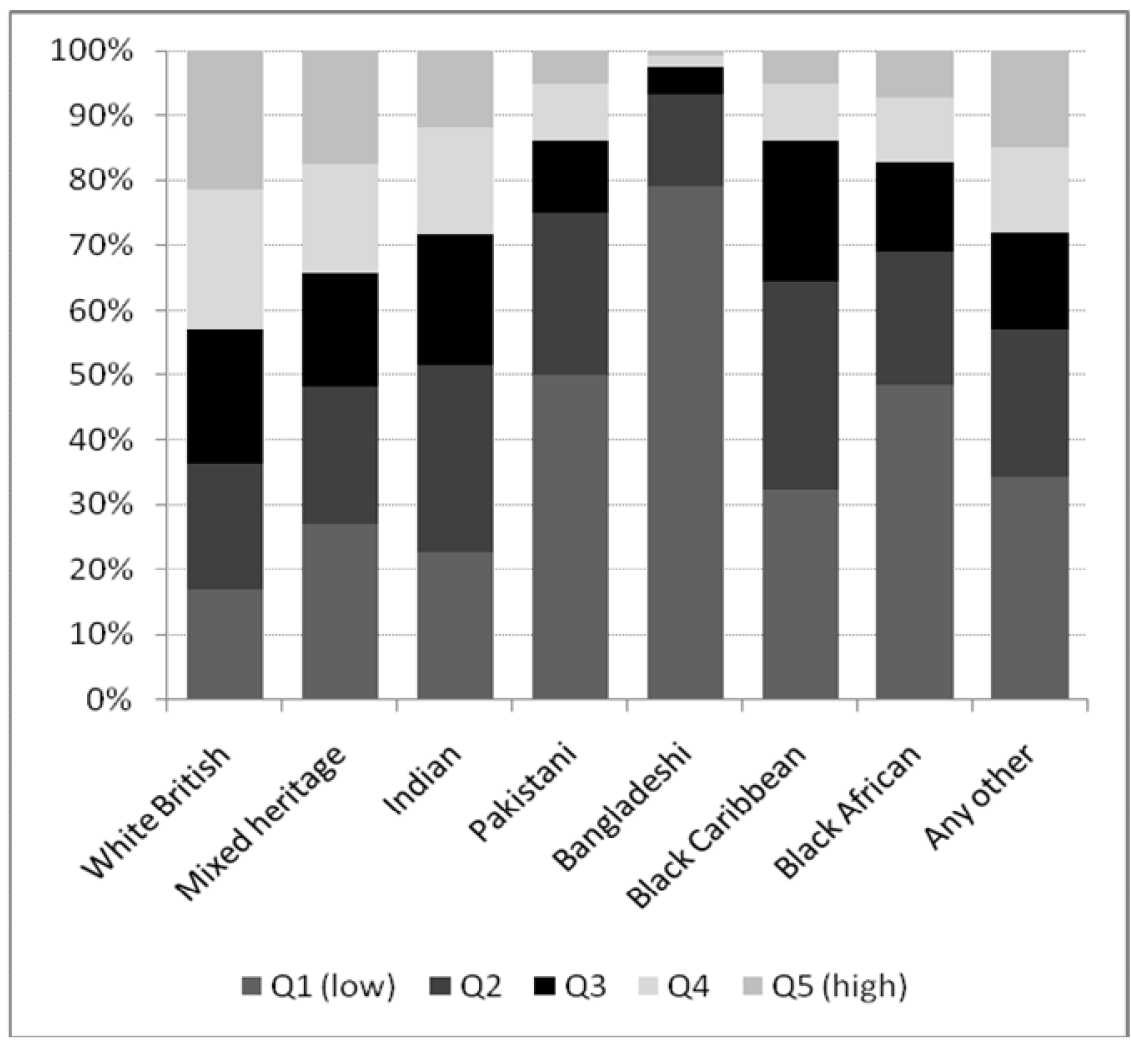


Figure 3: GCSE attainment by Ethnic group and SES (main effects model)

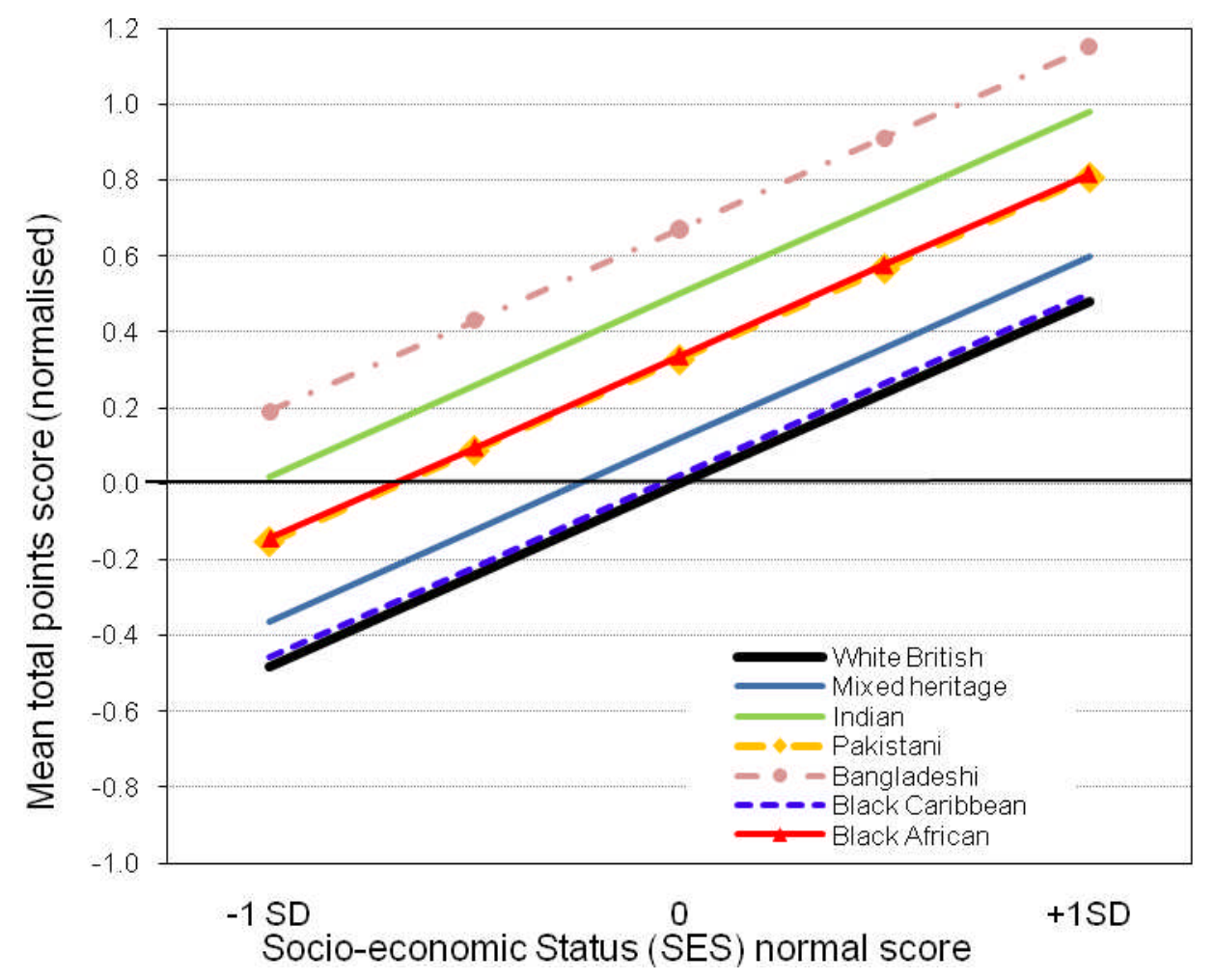


Figure 4: Age 16 points score by ethnic group, gender and SES showing interactions (Model 2)
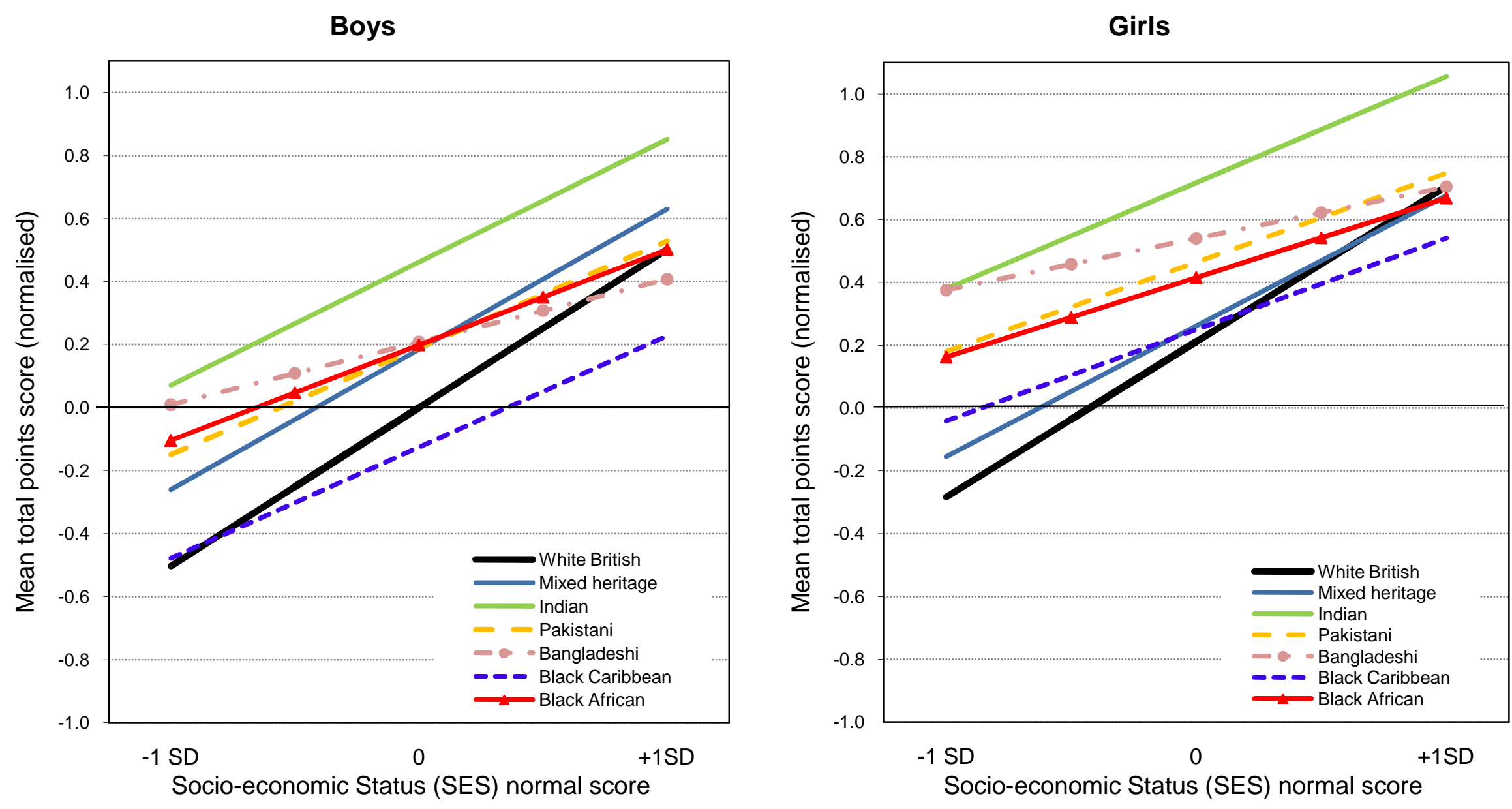

$\underline{\text { Note: }}$ These charts omit 'Any other ethnic group' for greater clarity. 
Figure 5: Student progress by ethnic group, SES, gender and prior attainment (Model 2)

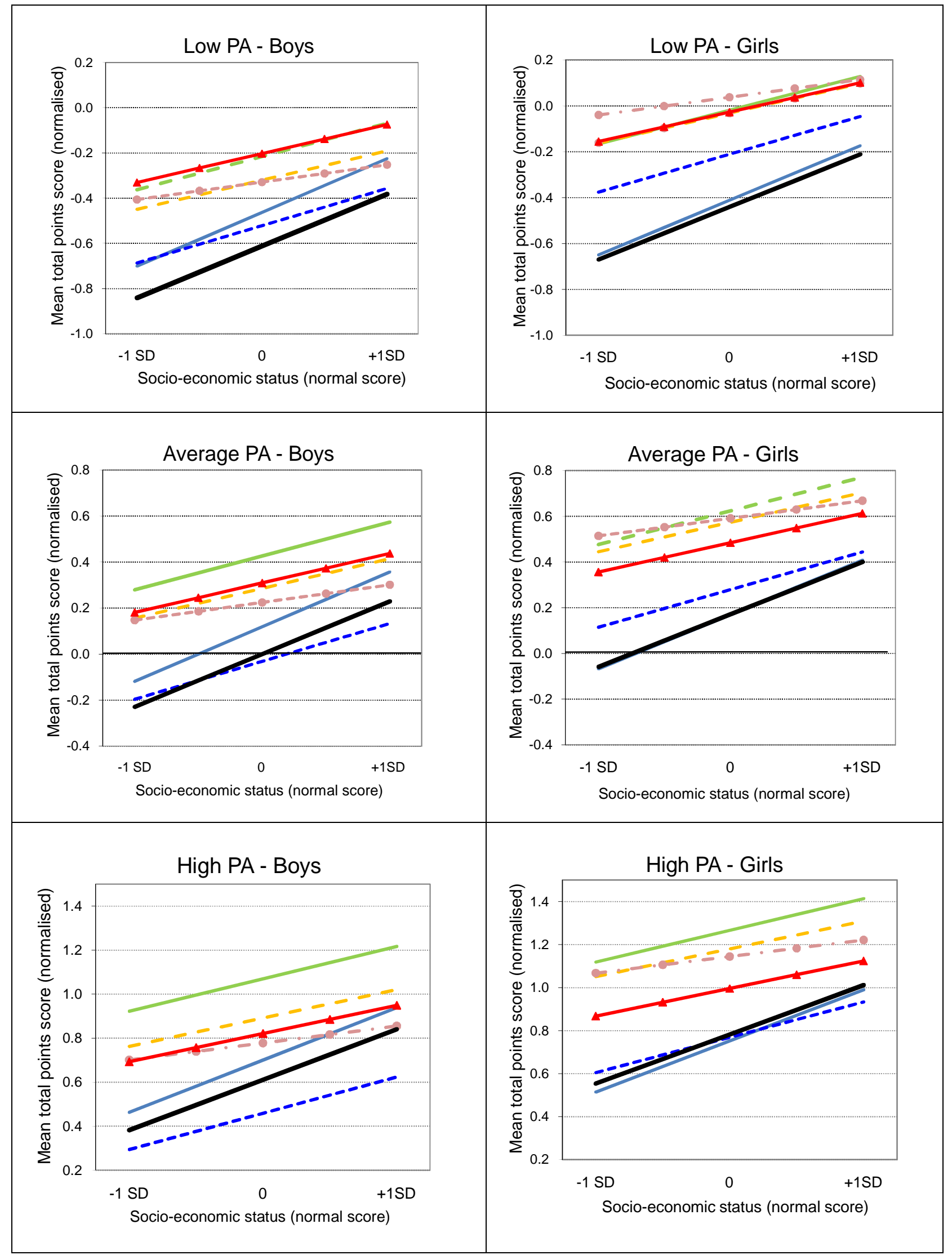

Panels are labelled (a)-(f) from top left to bottom right. These present the mean progress age 11-16 by ethnic group, SES and gender of: (a)/(b) boys/girls with low (-1 SD) prior attainment at age 11 (c)/(d) boys/girls with average prior attainment at age 11; (e)/(f) boy/girls with high $(+1 S D)$ prior attainment at age 11. Statistically significant contrasts are indicated in Appendix 1. 
Figure 6: Mean normal score at age 11, age 14 and age 16 by ethnic group at bottom, middle and upper SES quintiles
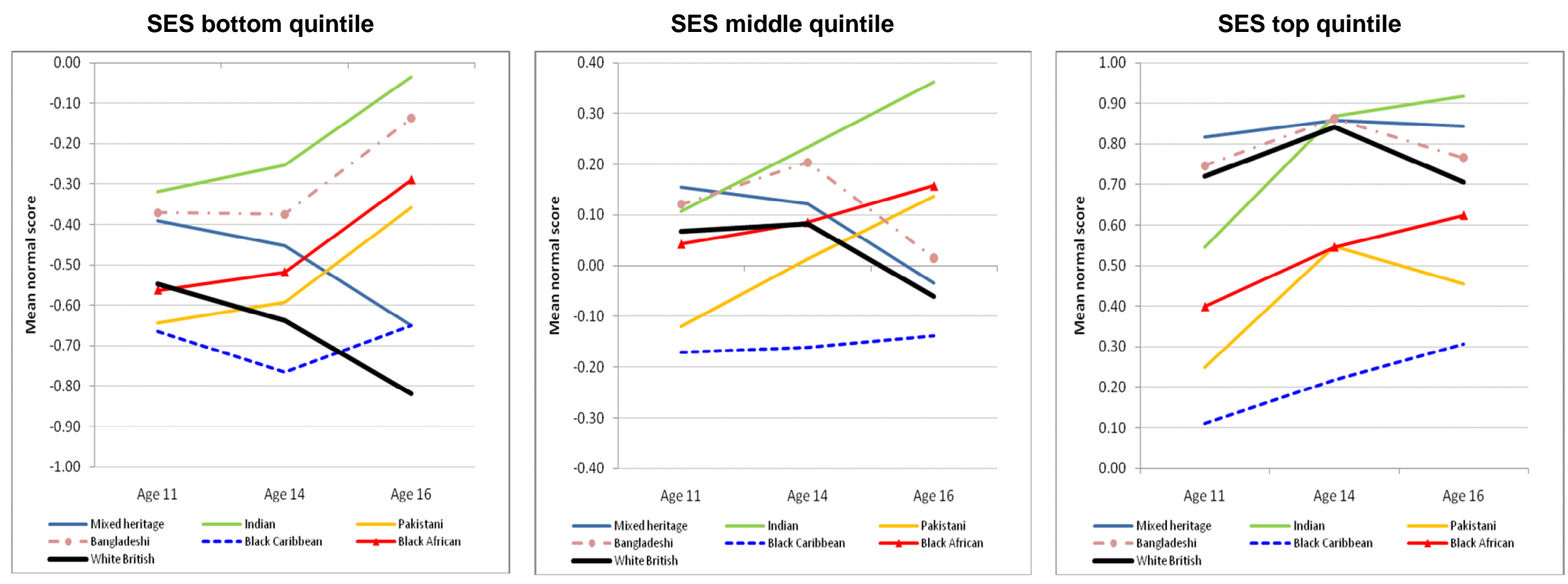

Notes: Age 16 score is the normalised core points score (CPS) so scores at all three time points are based only on English, mathematics and science tests/exams. Mixed heritage and any other ethnic group are excluded for clarity. 
Appendix 1: Progress age 11-16 points score by ethnic group, gender and SES (Model 2)

\begin{tabular}{|c|c|c|c|c|c|c|c|c|}
\hline \multirow{3}{*}{ Age 11} & \multirow[b]{3}{*}{ Sex } & \multirow[b]{3}{*}{ Ethnic group } & \multicolumn{3}{|c|}{ Mean age 16 score } & \multicolumn{3}{|c|}{ Difference from White British } \\
\hline & & & \multicolumn{3}{|c|}{ SES } & \multicolumn{3}{|c|}{$\begin{array}{l}\text { SES } \\
\end{array}$} \\
\hline & & & $-1 S D$ & mean & $+1 S D$ & $-1 \mathrm{SD}$ & mean & $+1 S D$ \\
\hline Low & Boys & White British & -0.84 & -0.61 & -0.38 & - & - & - \\
\hline \multirow[t]{15}{*}{$(-1 \mathrm{SD})$} & & Mixed heritage & -0.70 & -0.46 & -0.22 & $0.14+$ & $0.15+$ & $0.16+$ \\
\hline & & Indian & -0.36 & -0.22 & -0.07 & $0.48++$ & $0.40++$ & $0.31++$ \\
\hline & & Pakistani & -0.45 & -0.32 & -0.19 & $0.39++$ & $0.29++$ & $0.19++$ \\
\hline & & Bangladeshi & -0.41 & -0.33 & -0.25 & $0.43++$ & $0.28++$ & 0.13 \\
\hline & & Black Caribbean & -0.69 & -0.52 & -0.36 & $0.15++$ & $0.09+$ & 0.03 \\
\hline & & Black African & -0.33 & -0.20 & -0.07 & $0.51++$ & $0.41++$ & $0.31++$ \\
\hline & & Any other group & -0.34 & -0.29 & -0.24 & $0.50++$ & $0.32++$ & $0.15+$ \\
\hline & Girls & White British & -0.67 & -0.44 & -0.21 & - & - & - \\
\hline & & Mixed heritage & -0.65 & -0.41 & -0.17 & 0.02 & 0.03 & 0.04 \\
\hline & & Indian & -0.17 & -0.02 & 0.13 & $0.50++$ & $0.42++$ & $0.34++$ \\
\hline & & Pakistani & -0.16 & -0.03 & 0.10 & $0.51++$ & $0.41++$ & $0.31++$ \\
\hline & & Bangladeshi & -0.04 & 0.04 & 0.11 & $0.63++$ & $0.48++$ & $0.33++$ \\
\hline & & Black Caribbean & -0.38 & -0.21 & -0.05 & $0.29++$ & $0.23++$ & $0.17++$ \\
\hline & & Black African & -0.16 & -0.03 & 0.10 & $0.51++$ & $0.41++$ & $0.31++$ \\
\hline & & Any other group & -0.11 & -0.06 & 0.00 & $0.56++$ & $0.38++$ & $0.21++$ \\
\hline Average & Boys & White British & -0.23 & 0.00 & 0.23 & - & - & - \\
\hline \multirow[t]{15}{*}{ (0 SD) } & & Mixed heritage & -0.12 & 0.12 & 0.36 & $0.11+$ & $0.12++$ & $0.13+$ \\
\hline & & Indian & 0.28 & 0.43 & 0.57 & $0.51++$ & $0.43++$ & $0.34++$ \\
\hline & & Pakistani & 0.16 & 0.29 & 0.41 & $0.39++$ & $0.29++$ & $0.19++$ \\
\hline & & Bangladeshi & 0.15 & 0.22 & 0.30 & $0.38++$ & $0.22++$ & 0.07 \\
\hline & & Black Caribbean & -0.20 & -0.03 & 0.13 & 0.03 & -0.03 & -0.10 \\
\hline & & Black African & 0.18 & 0.31 & 0.44 & $0.41++$ & $0.31++$ & $0.21++$ \\
\hline & & Any other group & 0.26 & 0.31 & 0.36 & $0.49++$ & $0.31++$ & $0.13+$ \\
\hline & Girls & White British & -0.06 & 0.17 & 0.40 & - & - & - \\
\hline & & Mixed heritage & -0.07 & 0.17 & 0.41 & -0.01 & 0.00 & 0.01 \\
\hline & & Indian & 0.48 & 0.62 & 0.77 & $0.53++$ & $0.45++$ & $0.37++$ \\
\hline & & Pakistani & 0.44 & 0.57 & 0.70 & $0.50++$ & $0.40++$ & $0.30++$ \\
\hline & & Bangladeshi & 0.51 & 0.59 & 0.67 & $0.57++$ & $0.42++$ & $0.27++$ \\
\hline & & Black Caribbean & 0.11 & 0.28 & 0.44 & $0.17++$ & $0.11++$ & 0.04 \\
\hline & & Black African & 0.36 & 0.48 & 0.61 & $0.41++$ & $0.31++$ & $0.21++$ \\
\hline & & Any other group & 0.49 & 0.54 & 0.60 & $0.55++$ & $0.37++$ & $0.20++$ \\
\hline High & Boys & White British & 0.38 & 0.61 & 0.84 & - & - & - \\
\hline \multirow[t]{15}{*}{$(+1 \mathrm{SD})$} & & Mixed heritage & 0.46 & 0.70 & 0.94 & 0.08 & 0.09 & 0.10 \\
\hline & & Indian & 0.92 & 1.07 & 1.22 & $0.54++$ & $0.46++$ & $0.38++$ \\
\hline & & Pakistani & 0.76 & 0.89 & 1.02 & $0.38++$ & $0.28++$ & $0.18++$ \\
\hline & & Bangladeshi & 0.70 & 0.78 & 0.86 & $0.32++$ & 0.17 & 0.01 \\
\hline & & Black Caribbean & 0.29 & 0.46 & 0.62 & -0.09 & $-0.15--$ & $-0.22--$ \\
\hline & & Black African & 0.69 & 0.82 & 0.95 & $0.31++$ & $0.21++$ & 0.11 \\
\hline & & Any other group & 0.86 & 0.91 & 0.96 & $0.48++$ & $0.30++$ & 0.12 \\
\hline & Girls & White British & 0.55 & 0.78 & 1.01 & - & - & - \\
\hline & & Mixed heritage & 0.51 & 0.75 & 0.99 & -0.04 & -0.03 & -0.02 \\
\hline & & Indian & 1.12 & 1.27 & 1.41 & $0.57++$ & $0.48++$ & $0.40++$ \\
\hline & & Pakistani & 1.05 & 1.18 & 1.31 & $0.50++$ & $0.40++$ & $0.30++$ \\
\hline & & Bangladeshi & 1.07 & 1.14 & 1.22 & $0.51++$ & $0.36++$ & $0.21+$ \\
\hline & & Black Caribbean & 0.60 & 0.77 & 0.93 & 0.05 & -0.01 & -0.08 \\
\hline & & Black African & 0.87 & 1.00 & 1.12 & $0.31++$ & $0.21++$ & 0.11 \\
\hline & & Any other group & 1.09 & 1.14 & 1.20 & $0.54++$ & $0.36++$ & $0.18++$ \\
\hline
\end{tabular}

Note: The reference category is White British, boys at mean SES and mean age 11 score (indicated as $0.00)$ and age 16 score estimates are relative to this base group. The significance tests compare each ethnic group to White British pupils within each SES and gender combination. A plus sign (+) indicates the group scored significantly higher than White British, while a negative sign (-) indicates the group scored significantly lower than White British $(-/+=p<.05,--/++=p<.01)$. For standard errors see Table 7. 
Appendix 2: Contextual value added age 11-16 by ethnic group, gender and SES (Model

5)

\begin{tabular}{|c|c|c|c|c|c|c|c|c|}
\hline \multirow{3}{*}{$\begin{array}{l}\text { Age } 11 \\
\text { score }\end{array}$} & \multirow[b]{3}{*}{ Sex } & \multirow[b]{3}{*}{ Ethnic group } & \multicolumn{3}{|c|}{ Mean age 16 score } & \multicolumn{3}{|c|}{ Difference from White British } \\
\hline & & & \multicolumn{3}{|c|}{ SES } & \multicolumn{3}{|c|}{ SES } \\
\hline & & & $-1 S D$ & mean & +1SD & $-1 \mathrm{SD}$ & mean & +1SD \\
\hline Low & Boys & White British & -0.56 & -0.46 & -0.37 & & & \\
\hline \multirow[t]{15}{*}{$(-1 \mathrm{SD})$} & & Mixed heritage & -0.45 & -0.34 & -0.24 & $0.11++$ & $0.12+$ & 0.13 \\
\hline & & Indian & -0.45 & -0.37 & -0.30 & $0.12++$ & $0.09+$ & 0.07 \\
\hline & & Pakistani & -0.54 & -0.49 & -0.45 & 0.03 & -0.03 & -0.08 \\
\hline & & Bangladeshi & -0.51 & -0.52 & -0.53 & 0.05 & -0.06 & -0.16 \\
\hline & & Black Caribbean & -0.53 & -0.48 & -0.43 & 0.03 & -0.02 & -0.06 \\
\hline & & Black African & -0.41 & -0.35 & -0.28 & $0.15++$ & $0.12+$ & 0.09 \\
\hline & & Any other group & -0.33 & -0.32 & -0.32 & $0.23++$ & $0.14++$ & 0.05 \\
\hline & Girls & White British & -0.50 & -0.36 & -0.22 & & & \\
\hline & & Mixed heritage & -0.42 & -0.28 & -0.13 & 0.08 & $0.08+$ & 0.09 \\
\hline & & Indian & -0.30 & -0.18 & -0.07 & $0.20++$ & $0.18++$ & $0.15++$ \\
\hline & & Pakistani & -0.26 & -0.17 & -0.08 & $0.24++$ & $0.19++$ & $0.14+$ \\
\hline & & Bangladeshi & -0.14 & -0.11 & -0.08 & $0.36++$ & $0.25++$ & 0.15 \\
\hline & & Black Caribbean & -0.35 & -0.25 & -0.16 & $0.15++$ & $0.11++$ & 0.07 \\
\hline & & Black African & -0.26 & -0.15 & -0.05 & $0.24++$ & $0.21++$ & $0.17+$ \\
\hline & & Any other group & -0.18 & -0.13 & -0.08 & $0.32++$ & $0.23++$ & $0.14+$ \\
\hline Average & Boys & White British & -0.10 & 0.00 & 0.10 & & & \\
\hline \multirow[t]{15}{*}{ (0 SD) } & & Mixed heritage & -0.02 & 0.09 & 0.19 & 0.08 & $0.09+$ & 0.09 \\
\hline & & Indian & 0.10 & 0.17 & 0.25 & $0.20++$ & $0.17++$ & $0.15++$ \\
\hline & & Pakistani & -0.02 & 0.03 & 0.07 & $0.08+$ & 0.03 & -0.02 \\
\hline & & Bangladeshi & -0.05 & -0.06 & -0.07 & 0.05 & -0.06 & -0.17 \\
\hline & & Black Caribbean & -0.15 & -0.10 & -0.04 & -0.05 & $-0.10--$ & $-0.14--$ \\
\hline & & Black African & 0.00 & 0.06 & 0.13 & 0.10 & 0.06 & 0.03 \\
\hline & & Any other group & 0.16 & 0.17 & 0.18 & $0.26++$ & $0.17++$ & 0.08 \\
\hline & Girls & White British & -0.03 & 0.10 & 0.24 & & & \\
\hline & & Mixed heritage & 0.01 & 0.15 & 0.30 & 0.04 & 0.05 & 0.06 \\
\hline & & Indian & 0.25 & 0.36 & 0.48 & $0.28++$ & $0.26++$ & $0.23++$ \\
\hline & & Pakistani & 0.26 & 0.35 & 0.44 & $0.30++$ & $0.24++$ & $0.19++$ \\
\hline & & Bangladeshi & 0.32 & 0.35 & 0.38 & $0.36++$ & $0.25++$ & 0.14 \\
\hline & & Black Caribbean & 0.04 & 0.13 & 0.23 & 0.07 & 0.03 & -0.02 \\
\hline & & Black African & 0.15 & 0.26 & 0.36 & $0.18++$ & $0.15++$ & 0.12 \\
\hline & & Any other group & 0.31 & 0.36 & 0.41 & $0.35++$ & $0.26++$ & $0.16++$ \\
\hline High & Boys & White British & 0.37 & 0.46 & 0.56 & & & \\
\hline \multirow[t]{15}{*}{$(+1 \mathrm{SD})$} & & Mixed heritage & 0.42 & 0.52 & 0.62 & 0.05 & 0.05 & 0.06 \\
\hline & & Indian & 0.65 & 0.72 & 0.79 & $0.28++$ & $0.26++$ & $0.23++$ \\
\hline & & Pakistani & 0.50 & 0.55 & 0.59 & $0.14++$ & 0.08 & 0.03 \\
\hline & & Bangladeshi & 0.41 & 0.40 & 0.39 & 0.04 & -0.07 & -0.17 \\
\hline & & Black Caribbean & 0.23 & 0.29 & 0.34 & $-0.14--$ & $-0.18--$ & $-0.22--$ \\
\hline & & Black African & 0.41 & 0.47 & 0.54 & 0.04 & 0.01 & -0.02 \\
\hline & & Any other group & 0.66 & 0.66 & 0.67 & $0.29++$ & $0.20++$ & 0.11 \\
\hline & Girls & White British & 0.43 & 0.57 & 0.71 & & & \\
\hline & & Mixed heritage & 0.44 & 0.59 & 0.73 & 0.01 & 0.02 & 0.02 \\
\hline & & Indian & 0.80 & 0.91 & 1.03 & $0.37++$ & $0.34++$ & $0.32++$ \\
\hline & & Pakistani & 0.78 & 0.87 & 0.96 & $0.35++$ & $0.30++$ & $0.25++$ \\
\hline & & Bangladeshi & 0.78 & 0.81 & 0.84 & $0.35++$ & $0.24++$ & 0.13 \\
\hline & & Black Caribbean & 0.42 & 0.51 & 0.61 & -0.01 & -0.05 & -0.10 \\
\hline & & Black African & 0.56 & 0.67 & 0.77 & 0.13 & 0.10 & 0.07 \\
\hline & & Any other group & 0.80 & 0.85 & 0.90 & $0.37++$ & $0.28++$ & $0.19++$ \\
\hline
\end{tabular}

Note: All notes as for Appendix 1, except the model includes all control variables (see Table 7, model 5). 
Appendix 3: Mean normalised score at age 11, age 14 and age 16 by ethnic group and SES quintile

\begin{tabular}{|c|c|c|c|c|c|c|c|c|c|c|}
\hline \multirow[b]{2}{*}{ Ethnic group } & \multirow{2}{*}{$\begin{array}{c}\text { SES } \\
\text { quintile }\end{array}$} & \multicolumn{3}{|c|}{ Age 11} & \multicolumn{3}{|c|}{ Age 14} & \multicolumn{3}{|c|}{ Age 16} \\
\hline & & Mean & SE & $\mathrm{N}$ & Mean & SE & $\mathrm{N}$ & Mean & SE & $\mathrm{N}$ \\
\hline \multirow[t]{5}{*}{ White British } & 1 & -.55 & .02 & 1655 & -.64 & .02 & 1611 & -.82 & .02 & 1655 \\
\hline & 2 & -.20 & .02 & 1866 & -.23 & .02 & 1837 & -.37 & .02 & 1866 \\
\hline & 3 & .07 & .02 & 1980 & .08 & .02 & 1967 & -.06 & .02 & 1980 \\
\hline & 4 & .31 & .02 & 1959 & .36 & .02 & 1948 & .25 & .02 & 1959 \\
\hline & 5 & .72 & .02 & 1689 & .84 & .03 & 1678 & .71 & .02 & 1689 \\
\hline \multirow[t]{5}{*}{ Mixed heritage } & 1 & -.39 & .06 & 223 & -.45 & .05 & 218 & -.65 & .05 & 223 \\
\hline & 2 & -.07 & .07 & 157 & -.05 & .06 & 157 & -.15 & .06 & 157 \\
\hline & 3 & .16 & .07 & 121 & .12 & .06 & 120 & -.03 & .07 & 121 \\
\hline & 4 & .23 & .09 & 113 & .41 & .09 & 113 & .24 & .09 & 113 \\
\hline & 5 & .82 & .10 & 91 & .86 & .08 & 91 & .84 & .09 & 91 \\
\hline \multirow[t]{5}{*}{ Indian } & 1 & -.32 & .05 & 251 & -.25 & .05 & 248 & -.04 & .05 & 251 \\
\hline & 2 & -.06 & .05 & 265 & .07 & .05 & 264 & .20 & .05 & 265 \\
\hline & 3 & .11 & .06 & 191 & .23 & .05 & 191 & .36 & .05 & 191 \\
\hline & 4 & .30 & .06 & 152 & .46 & .06 & 151 & .48 & .06 & 152 \\
\hline & 5 & .54 & .10 & 91 & .87 & .11 & 91 & .92 & .10 & 91 \\
\hline \multirow[t]{5}{*}{ Pakistani } & 1 & -.64 & .04 & 485 & -.59 & .03 & 483 & -.36 & .03 & 485 \\
\hline & 2 & -.38 & .05 & 214 & -.28 & .06 & 212 & -.08 & .05 & 214 \\
\hline & 3 & -.12 & .07 & 87 & .01 & .07 & 86 & .14 & .07 & 87 \\
\hline & 4 & .08 & .15 & 44 & .37 & .12 & 44 & .49 & .13 & 44 \\
\hline & 5 & .25 & .20 & 25 & .55 & .20 & 25 & .45 & .22 & 25 \\
\hline \multirow[t]{5}{*}{ Bangladeshi } & 1 & -.37 & .04 & 531 & -.38 & .04 & 527 & -.14 & .04 & 531 \\
\hline & 2 & -.10 & .08 & 84 & .00 & .07 & 84 & .19 & .06 & 84 \\
\hline & 3 & .12 & .41 & 17 & .20 & .43 & 17 & .02 & .27 & 17 \\
\hline & 4 & .18 & .17 & 10 & .64 & .24 & 10 & .77 & .37 & 10 \\
\hline & 5 & .75 & .46 & 5 & .86 & .37 & 5 & .77 & .42 & 5 \\
\hline \multirow[t]{5}{*}{ Black Caribbean } & 1 & -.66 & .07 & 161 & -.77 & .06 & 161 & -.65 & .05 & 161 \\
\hline & 2 & -.35 & .06 & 157 & -.40 & .05 & 156 & -.35 & .05 & 157 \\
\hline & 3 & -.17 & .07 & 111 & -.16 & .07 & 111 & -.14 & .07 & 111 \\
\hline & 4 & .42 & .11 & 45 & .37 & .10 & 45 & .23 & .10 & 45 \\
\hline & 5 & .11 & .15 & 27 & .22 & .16 & 27 & .31 & .13 & 27 \\
\hline \multirow[t]{5}{*}{ Blak African } & 1 & -.56 & .05 & 203 & -.52 & .04 & 203 & -.29 & .05 & 203 \\
\hline & 2 & -.24 & .13 & 82 & -.14 & .11 & 80 & .07 & .08 & 82 \\
\hline & 3 & .04 & .10 & 57 & .09 & .10 & 57 & .16 & .13 & 57 \\
\hline & 4 & .06 & .17 & 40 & .37 & .10 & 40 & .54 & .07 & 40 \\
\hline & 5 & .40 & .21 & 33 & .55 & .22 & 33 & .62 & .18 & 33 \\
\hline \multirow[t]{5}{*}{ Any Other Group } & 1 & -.41 & .08 & 176 & -.24 & .07 & 175 & -.11 & .06 & 176 \\
\hline & 2 & -.05 & .09 & 128 & .20 & .09 & 128 & .33 & .09 & 128 \\
\hline & 3 & .25 & .10 & 67 & .28 & .11 & 67 & .21 & .10 & 67 \\
\hline & 4 & .17 & .11 & 72 & .22 & .12 & 72 & .21 & .10 & 72 \\
\hline & 5 & .98 & .11 & 53 & 1.26 & .11 & 53 & 1.14 & .11 & 53 \\
\hline
\end{tabular}

Notes: Age 16 score is the normalised core points score (CPS) so scores at all three time points are based only on English, mathematics and science tests/exams. 


\section{Footnotes}

'. Prior to 2003 a different ethnic coding system was used in the school census with no direct mapping between to the new codes, thus data prior to 2003 is not directly comparable with current figures.

ii . Non-linear or categorical Principal Component Analysis (PCA) was warranted for two reasons. First, it does not require the assumption that all variables are continuous scales and that the relationship between all variables are linear. Second, the optimal scaling approach offers a sophisticated option for handling missing data which does not use assumptions such as MAR (missing at random) or MCAR (missing completely at random). This treatment is possible in nonlinear PCA because its solution is not derived from the correlation matrix (which cannot be computed with missing values) but from the data themselves (see Meulman et al., 2004 and Linting et al., 2007 for further details).

iii. This is indicated by the fact that from 2006 onwards the key benchmark at age 16 is achieving five or more GCSE $A^{*}-C$ grades or equivalent including English and mathematics. Previously there was no specification of individual subjects within the five passes, which could be in any subject.

iv. Of course this does depend on how we express the ethnic gap. If we took this as the largest gap between an ethnic minority and the majority (White British) group, this would be 0.34 SD, so the SES gap would four times larger than the ethnic gap. However here we have chosen the broader measure of the gap between the highest and lowest achieving ethnic groups (0.63 SD).

v. The SES gap among girls reduces by a slightly smaller amount, from .99 SD to .49 SD (see Tables $4 \& 5$ ) or a $50 \%$ reduction. This reflects a significant gender by SES interaction in model 5 (see Table 3), so that for White British students, after controlling for all the contextual variables, the gender gap is small and non significant at low SES (.02 SD) compared to 09 SD at the mean SES and .15 SD at high SES.

vi. Full crosstabulations of ethnic group by each of the contextual variables are given as Appendix 2 in Strand (2011) and so are not repeated here.

vii. This is not just because these two authors used a simple binary measure (whether a student gained 5 or more GCSEs at $A^{*}-C$ grades or not) rather than a continuous outcome, since a 
logistic regression on the $5+A^{*}-C$ including English and mathematics threshold measure with the LSYPE data also revealed significant ethnic by SES interactions. It is more likely to reflect better estimates of SES (direct measures across a range of SES variables rather than student report of parental occupation) and better sampling because of the LSYPE boost for minority ethnic groups.

viii. This phenomena is observed across a range of SES variables not just parental socioeconomic classification (SEC), but because the same patterns are seen when using just the SEC of the home, the term 'working class' is an appropriate to unite these findings.

ix. LSYPE was able to distinguish between students who spoke English only, had English as their first/main language although they spoke other languages as well, or were bilingual, in contrast to those whose first/main language was other than English on the other. The latter group accounted for $42 \%$ of Bangladeshi, $26 \%$ of Pakistani, $25 \%$ of Black African and $17 \%$ of Indian students.

${ }^{x}$. EAL has not been included in the models reported here because of this non-significant effect. Kingdon \& Cassen (2010) note the same finding.

${ }^{x i}$. Despite this, we should be wary of an uncritical interpretation of educational aspirations as evidence of psychological dispositions to achieve, or of a simple causal relationship between aspirations and subsequent attainment (Strand \& Winston, 2008). High levels of intending to continue in FTE among minority groups may actually reflect students' knowledge of the greater risk of unemployment for young members of minority ethnic groups relative to Whites if they enter the labour market at 16 , together with the fear of racial discrimination in the workplace (Payne, 2003). White British students may have lower 'educational aspirations' because they do not face these barriers.

xii. General National Vocational Qualifications (GNVQs) are alternatives to GCSE examinations that emphasise vocational aspects of the curriculum, although both GNVQ and GCSE are awarded points values of the same unified scale. 